University of Rhode Island

DigitalCommons@URI

Open Access Master's Theses

1982

\title{
Politics, Planning and Regional Mall Development: The Case of Webster, New York
}

Michael E. Embury

University of Rhode Island

Follow this and additional works at: https://digitalcommons.uri.edu/theses

\section{Recommended Citation}

Embury, Michael E., "Politics, Planning and Regional Mall Development: The Case of Webster, New York" (1982). Open Access Master's Theses. Paper 645.

https://digitalcommons.uri.edu/theses/645

This Thesis is brought to you for free and open access by DigitalCommons@URI. It has been accepted for inclusion in Open Access Master's Theses by an authorized administrator of DigitalCommons@URI. For more information, please contact digitalcommons-group@uri.edu. 
Master of Community Planning Thesis Project

of

Michael E. Embury

APPROVED :

Major Professor

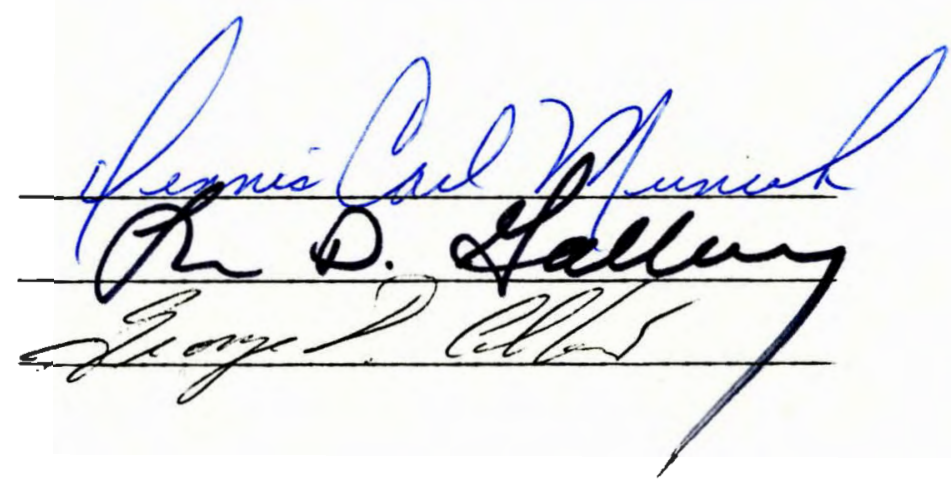

UNIVERSITY OF RHODE ISLAND

1982 
POLITICS, PLANNING AND REGIONAL MALL DEVELOPMENT:

The Case of Webster, New York. 
TABLE OF CONTENTS

Chapter I: Introduction ....................... Page 1.

Chapter II: Town of Webster: Context for Development....... Page 8.

Chapter III: New York State Environmental Quality Review Act $(\mathrm{SEQR}) \ldots \ldots \ldots \ldots \ldots \ldots \ldots \ldots \ldots$ Page 17.

Chapter IV: Chronology of Events................... Page 25.

Chapter v: Analysis......................... Page 33 .

Chapter vI: Conclusion......................... Page 46 . TABLES

Table 1. Regional/SMSA Population 1970-1985............. Page 8.

Table 2. Population and Housing Data 1970-1985.......... Page 9.

Table 3. Mal1 Comparisons...................... Page 13.

Table 4. Mall Marketing Characteristics................. Page 13.

Table 5. Impact of Webster Mall on Existing Regional

Facilities................................ 14 .

Table 6. Impact of Expressway Mall on Existing Regional

Facilities.......................... Page 14.

MAPS

Map 1. Regional Orientation.

Map 2. Area Shopping Facilities.

Map 3. Webster Mall Site.

Map 4. Expressway Mall Site.

Map 5. Webster Zoning

Map 6. General Development Plan for Monroe County. 


\section{APPENDICIES}

Appendix 1. Maps

Appendix 2. New York State Environmental Quality Review Act (SEOQR).

Appendix 3. Webster Zoning Ordinance Relating to Planned Unit

Commercial Development. 
CHAPTER I. Introduction

Regional mall development usually elicits one of two responses -- wholesale support or wholesale rejection of the development proposal. Major mall developments involve all three sectors of the economic and policy making process: 1) the private sector, which is basically responsible for initiating the development proposal; 2) the public sector, which is responsible for protecting the "public interest"; and 3) private citizens within the affected jurisdiction who form support or opposition groups to the development as a means of insuring effective input throughout the process.

The political and economic ramifications of major retail development are numerous and have long-term, permanent effects upon an entire region, as well as the municipality in which they are located. The location and siting of regional malls has caused numerous debates because of these ramifications. A major issue revolves around whether the siting of these facilities serve as the impetus for commercial sprawl or result from the deficiencies in the local retail market. (Simmons, 1964: 1-14; Sternleib and Hughes, 1981; Schmore, 1963: 26, 30-32; Tucker, 1981: 41, in Sternleib and Hughes; Yehoshua, 1972: 25.) Determining this type of cause and effect relationship is difficult at best and relies heavily upon the area involved and previous development patterns. The land development process, and the political processes that are assoicated with it, are issues that planners must deal with on a daily basis. The manner in which the planning process works among all of the above pressures depends, to a large extent, 
upon one's theoretical perspective. While a generalized view of regional mall development may be useful, the most useful analysis occurs at a localized level, when viewing the effects of a mall on that area.

Government regulation has increased on all levels throughout the last decade. Popular theory places the burden of development delay upon the government agencies who are responsible for enforcing these regulations. Developers, Chambers of Comerce, and general business interests are constantly blaming red tape and delays on planners and other local officials. (Sternleib and Hughes, 1981.) Some basic notions are called into play when one attempts to analyze where the blame lies. Local government bodies are certainly responsible for some delay, but as developers compete for increasingly scarce and prime commercial sites, they are also responsible for numerous delays.

The case before us involves the Town of Webster, New York. Webster is located in the northeastern portion of Monroe County, just east of Rochester, New York. Two national development firms have proposed separate, reglonal mall developments for the town, which have spurred a volatile debate in town. Extensive Iitigation (over two years) and delays have caused local residents to lay much of the blame at the feet of local officials. (Embury Interviews, 1981.) While this mall location controversy may appear to be nothing more than project selection by the town, the undercurrents are much more significant than that. Very strong economic forces are hard at work attempting to gain hold of the last, large commercial area in the county. 
This analysis demonstrates that the delays are a direct result of litigation between developers. While town officials have been parties to the lawsuits because of their administrative positions, they do not bear the primary responsibility for the delays. It is my premise that local government officials and regulations have become "straw men" which serve as the "scapegoats" and "whipping boys", while developers cause lengthy delays battling for very limited and prime commercial opportunities.

In the case of smaller, metropolitan communities like Webster, the government is placed in a position of responding and reacting to a development proposal. This reactive posture places the local government in a defensive position, making them appear "one step behind" the actions of the developers. This defensive posture leaves a perception of local government ineptness which results in delay. This perception endures in spite of any previous preparation or consequent actions that demonstarte otherwise. (A content analysis of local newspapers shows a tendency by some to blame the Webster delays on the local government. The local reporting has not addressed in any detail, that two competitors from a very select group are vying over a piece of valuable land and a captive market area.)

The question of an elite and its ensuing, local role has been continually debated over the years by such scholars as Domhoff (1970), Dah1 (1961), Hunter (1953), Mills (1963) and Arkes (1981). The Mills/ Hunter perspective points to a power elite that has the ability to influence any important question that arises in a community. This ability is not confined to positions of official authority. (Hunter, 
1953; Arkes, 1981: 260.) The Webster controversy points to the involvement of a number of local economic interests who are exerting a number of powerful influences over this development situation.

The Mills/Hunter context makes it likely that "public men will make decisions that are allied with self-interest, and the question is... whether their personal concerns can be connected in a more wholesome way to the interests of their constituents." (Arkes, 1981: 269.) The analysis section of this research will elaborate on whether Webster Town officials were in fact acting in self-interest and if their decisions did have the interests of their constituents at heart.

Within the context of governance and self-interest, government serves two principal functions: 1) supplying goods and services; 2) managing political conflicts in matters of public importance. In many instances, these two functions are indistingulshable because they are performed simultaneously by the same institutions. (Banfield and Wilson, 1974: 75.) The function of supplying goods and services is quite evident in day to day operations. The managing of public conflicts is not always as evident, but is in its essence local politics. It is inevitable that someone will always perceive the public good in a manner that is different from the perception of others. This difference of opinion gives rise to local political conflict. Essentially, politics becomes the process of discussing, dissecting and expanding the perception of the "public interest". This debate is reveled in by some participants, but many of the citizens find this process 
undesireable. It appears to them that decisions are based and implemented on considerations that have little to do with the issues themselves. Political, self-interested action though, does not necessarily preclude acting in the public interest. (Banfield and Wilson, 1974: 76.) As we review the Webster controversy, we must interpret the actions of town officials and assess the manner in which the public interest was addressed.

At some point in time, this political debate will and must involve the public and private sectors -- business and the "body politic". As part of their conflict management function, local government officials require developers to "jump through the proper hoops!" The hoop requirements are vital to both groups. In Webster, citizens had to keep abreast of local requirements so that they could "properly" participate in the mall debate. For developers, the monetary stakes were/are tremendous, but no more important than the citizen requirements. The knowledge of and ability to meet the application, hearing and permitting deadlines is the essential iffeblood for teh two developers in this case. The process transcends the exercise of brute power and becomes and exercise in the nuances of power. Reports, documents, public hearings and a variety of other responsibilities all translate into a considerable amount of pressure for the governing body at the local level, and specifically in Webster. (McBride and Clawson, 1970: 27-28.)

The pressure that is applied to local officials causes some to question the tenacity of the performance of duties by these officials. "Public officials are usually diligent in the performance of their 
duties. In a few cases the public is abused. Those who decide on behalf of the public are in a position of responding to a request on the issue. The applicant is the initiator, the government the accomodators." (McBride and Clawson, 1970: 27-28.) As accomodators, local government officials often lack adequate cost-benefit analyses and docimnetation that is independent from that provided by local developers. These officials are not necessarily in a position to demand information from the other branches of local government. The expertise and time may not be readily available. These officials must exert a great deal of effort and interest to stay abreast of the daily operations of local government. (McBride and Clawson, 1970: 27-28.)

Town of Webster officials have diligently pursued their duties during this controversy, although not everyone would concur with this assessment. This research supports the McBride/Clawson contention that independent cost-benefit analyses is not available to the local decision makers. Again, the reactionary posture local boards are placed in put them at a disadvantage in this process. Once the application process has begun, many localities do not have the technical support to conduct this type of analyses. In lieu, the decision makers must assess and rule on information that is provided by competing interests --- developer v. developer; citizens v. developer.

It is within this context that this study will seek to analyze the causes of a more than two year delay in the final approval process and the construction of a regional mall in Webster, New York. Several hypotheses are part of this analysis: 1) that the 
"failure" of the "local planning process" is not responsible for the excessive delays in developments; 2) that developers who are in competition for the same limited market will act in an obstructionist manner to protect their economic interests; 3) as a result of developer actions, citizen participation is solicited, but has little effect upon any substantive development decisions.

In order to explore these questions of process in depth, this project involves a case study approach which places events in an analytical perspective. A number of tasks has taken place for this analysis: review of the literature on locational theory, political theory, other mall development situations, state and local laws that are applicable, review of the technical aspects of both mall proposals -- impact statements and plans; interviews; review of the permit applications, reviews, planning board and town board minutes; and an analysis of the situation in light of our current understanding of the theoretical literature.

The Webster controversy provides an opportunity to analyze and observe a major development in process. Planners deal on a regular basis with development projects of a large magnitude. As these projects increase in size and importance, their effects become more critical. Exploring the manner in which large-scale projects are affected by, and have an effect on, the local planning process is crucial to developing a better understanding of that process. 
CHAPTER II. TOWn of Webster: Context for Development

Webster, New York is located in the eastern portion of Monroe County, just east of the City of Rochester, the third largest city in New York State. Until the 1950's, Webster was primarily a farming community which accepted minimal growth from the metropolitan area. During the $1950^{\prime}$ 's, Webster began the evolution from a farming community to a bedroom community for Rochester.

The following population figures supply a cursory demographic comparison for the SMSA, Monroe, Wayne anid Ontario Counties, Webster Town and Webster Village.

TABLE I. REGIONAL/SMSA POPULATION 1970 - 1985.

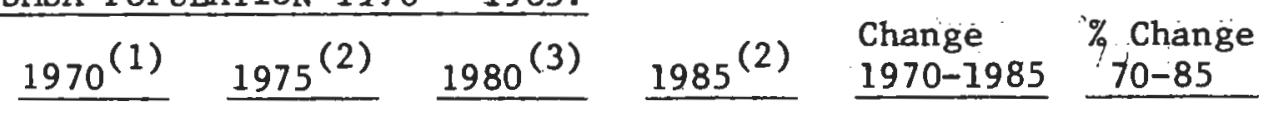

City of Rochester $295,011 \quad 265,000 \quad 241,539 \quad 254,000 \quad-41,011 \quad-13.9$

Monroe Co.

$\begin{array}{lllllll}\text { (Less Rochester) } & 416,906 & 463,000 & 459,992 & 494,810 & 77,904 & 18.7\end{array}$

Al1 Monroe Co. $\quad 711,917 \quad 728,000 \quad 701,531 \quad 748,810 \quad 36,893$

$\begin{array}{lllllll}\text { Wayne Co. } & 79,404 & 82,166 & 84,456 & 89,952 & 10,548 & 13.3\end{array}$

$\begin{array}{lllllll}\text { Ontario Co. } & 78,849 & 85,054 & 88,505 & 99,720 & 20,871 & 26.5\end{array}$

$\begin{array}{lllllll}\text { TOTAL SMSA } & 961,516 & 971,465 & 969,935 & 1,029,313 & 67,797 & 7.1\end{array}$

(1) 1970 U.S. Census

(2) 1975 County, City Data Book. Monroe County Department of Planning; New York State Economic Board, Center for Government Research.

(3) 1980 U.S. Census.

All of the above as cited in the Webster and Expressway Mall Draft Environmental Impact Statements. 
TABLE 2. POPULATION AND HOUSING DATA $1970-1980$.

\begin{tabular}{|c|c|c|c|c|c|c|c|c|}
\hline & \multicolumn{2}{|c|}{ Population } & \multirow[b]{2}{*}{1980} & \multirow[b]{2}{*}{$\underline{\%}$} & \multicolumn{3}{|c|}{ Housing Units } & \\
\hline & 1970 & $\underline{\%}$ & & & 1970 & $\underline{\%}$ & 1980 & $\%$ \\
\hline Monroè Co. & 711,917 & & 701,531 & & 228,554 & & 264,028 & \\
\hline Webster Town & 24,739 & $(3.4)$ & 28,895 & $(4.1)$ & 7,078 & $(3.0)$ & 10,066 & $(3.8)$ \\
\hline Webster Village & 5,037 & $(.07)$ & 5,486 & $(.07)$ & 1,607 & $(.07)$ & 2,189 & $(.08)$ \\
\hline Tota1 (Town/Village) & 29,776 & $(4.1)$ & 34,371 & $(4.9)$ & 8,685 & $(3.8)$ & 12,255 & $(4.6)$ \\
\hline
\end{tabular}

It is important to point out the reason for the Town/Village delineation. As can be observed in Map 5, the Village of Webster is completly surrounded by the Town of Webster. In New York State, very strict jurisdictional guidelines exist between towns and villages. Although the village is contained within the Town, each entity is a separate governmental unit responsible for governmental functions within their boundaries.

Webster Town and Village have grown from 1970 to 1980, while Monroe County has declined by some 10,386 over that same period. These figures demonstrate that Webster is a growth community which is "bucking the trend" of Monroe County.

Webster possesses a diversity of land use which includes a mixed housing stock, open space, farm land, recreational areas, commercial and industrial concentrations. This diversity serves as an attractor for new residents. As the eastenmost town in Monroe County, with the largest tracts of available developable 1and, Webster will continue to experience outward growth pressure from the Metropolitan area. It appears that Webster will grow in spite of the development posture of the Town. Webster also borders Wayne County (part of the Rochester SMSA) which is 
experiencing some growth and possesses no large regional commercial and retail center to accomodate its growth and market demands. (See Map 2. .)

Local government participation in the growth process involved a number of actors. In relation to the mall proposals, these actors have carried through a number of local elections and administrations, while others have only participated in certain phases along the way toward approval. This situation is a function of the terms of office of local officials. The Town Council consists of five (5) members -four (4) councilmen and the supervisor. Every two years the supervisor and two councilmen are subject to local, at-large elections. This type of system allows for some continuity but can lead to a shift in ruling majorities on the Council. It is necessary to identify the council officials who were responsible for the bulk of these proposals and involved in the majority of decisions. Three Republicans -- Supervisor Kent, Edward Heligman and Nancy Thomas and two Democrats -- Henry Kujawa and Robert Murphy -- were most directly involved in the more controversial aspects of this process. (Webster Herald 1980 - 1981.)

The Webster Town Planning Board also played an integral part in this process. The Planning Board consisted of William Gray, Joseph Maier, Elmer Welke and Tony Casciani. The Board is appointed by the Supervisor, contingent upon the Town Council approval, and 1ts members serve five (5) year terms. The Planning Board is responsible for reviewing sketch plans, development proposals, preliminary and final plan submissions. In order to integrate and understand the Planning Board's role in this particular controversy, it is beneficial to 
review the process which had to be followed.

The Webster Zoning process was applied to each of the two developments, since a zone change was necessary for each proposal. Each developer had to submit a sketch plan to the Planning Board, per 59-25 of the Webster Zoning Ordinance. Whether this plan meets the Board's approval or disapproval, written findings must be transmitted to the Council in writing. In the case of Planning Board approval, these findings serve as an advisory opinion to the Town Council. When the Board disapproves the sketch plan, the written findings serve as the record. The Town Council then reviewed these projects in accordance with the Planned Unit Development requirements (59-23-25) and must issue findings within sixty (60) days. Within six months of this review the developer must submit a preliminary plan which the Planning Board reviews. Their findings are transmitted to tke Town Council as an advisory opinion. The Town Council holds a public hearing before a decision is made. A final plan is then submitted for the same approvals. (Webster Town Zoning Ordinance.)

Although not a local public official, New York State Supreme Court Justice David 0 . Boehm played a significant role in this entire process. When the litigation began in this controversy, Judge Boehm handed down the decision which has carried the most weight throughout this process.

The ma11 controversy in Webster involves two national development rivals who have proposed regional shopping malls for sites that are approximately one-half mile apart. (See Map 5 .) The Expressway Mall development group is headed by National Shopping Centers, Inc. from Westchester County (the second largest mall developer in the country), 
with Rudy Starr serving as the developer. The J.C. Penney Realty Company (a subsidiary of the J.C. Penney Company), the McCurdy Company (a local department store and ma11 anchor), the Webster Coalition for Quality (a local citizens' group) and Bruce Hegedorn (a local land owner, long-time local businessman and owner of the Expressway Mall site). Mr. Hegedorn plays a very forceful role in this process and scenario, although not fronting the development operation. His presence in the development group lends a local identity and legitimization to the Expressway Mall proposal. His long established presence in Webster makes Hegedorn a "known quantity", readily identified by all town residents. This visibility places Hegedorn in a unique position which presents an advantage to the Expressway developers. (Webster Herald 1980 - 1981.)

The Webster Mall group has considerably fewer individuals and less locally influential actors than the Expressway Mall group. The list of coalescing parties includes the Sears subsidiary Homart Development Corporation, with Leonard Dobbs as developer. Webster Associates has been described as a coalition of local citizens and businessmen who have formed to promote the Webster Mall proposal. The Webster Coalition for Proper Planning is a local citizens' group which does not want the Expressway Mall proposal approved and which is actively working for the approval of the Webster Mall proposal. (Webster Herald 1980 - 1981.)

As a means of demonstrating the importance of these proposals to the town and the metropolitan region, it is useful to compare the marketing and physical characteristics of these two developments. 
TABLE 3. MALL COMPARISONS

Webster Mal1 $(1,3) \quad$ Expressway Mal1 $(2,3) \quad$ Total

Land Area

Gross Leasable Area

No. Major Stores

No. Retail Accessory Outlets

Parking Spaces
93 Acres

$905,000 \mathrm{sq} \cdot \mathrm{ft}$.

4

120

4600
95.8 Acres $780,000 \mathrm{sq}$. ft.

4

100

4200
188.8 Acres

$1,685,000 \mathrm{sq} . \mathrm{ft}$.

8

220

8800

SOURCES: (1) Webster Ma11: Larry Smith adn Company Marketing.

(2) Expressway Ma11: Gould Assoicates.

(3) Webster/Expressway Mal1 Draft Environmental Impact Statements.

TABLE 4. MALL MARKETING CHARACTERISTICS.

1. Approximately 250,000 people as market support.

2. Good location, access and local anchor stores.

3. Retail trade area: West - east side of Rochester

East - Wolcott (a town in Wayne County.)

South - Penfield, Macedon, Palmyra.

Zone A (primary) - Webster

Zone A (secondary) - South and East of the Town

Zone B (secondary) - East of Webster to Wolcott.

(See Map .)

4. Expenditure potential of market area:

$$
\begin{aligned}
& 1970-\$ 240,700,000 \\
& 1979-\$ 280,600,000 \\
& 1984-\$ 292,600,000 \\
& 1986-\$ 199,600,000
\end{aligned}
$$

SOURCES: Webster Mall: Larry Smith and Company Marketing.

Expressway Ma11: Gould Associates

Webster Mall/Expressway Mall Draft Environmental Impact Statements. (1980). 
TABLE 5. IMPACT OF WEBSTER MALI. ON EXISTING REGIONAL FACILITIES. (Mi11ions)

\begin{tabular}{|c|c|c|c|}
\hline & $\begin{array}{l}\text { Total } \\
\text { Sales } \\
070\end{array}$ & $\begin{array}{l}\text { Loss To } \\
\text { Webster } \mathrm{Ma} 11\end{array}$ & $\begin{array}{l}\% \text { Total } \\
\text { Sales } \\
\end{array}$ \\
\hline Rochester CBD & 87.0 & 8.0 & 9.0 \\
\hline Culver Ridge Plaza & 8.0 & 2.3 & 29.0 \\
\hline Irondequoit Area & 33.0 & 4.6 & 14.0 \\
\hline Primary Zone & 11.5 & 4.0 & 35.0 \\
\hline Panorama Plaza & 5.5 & 1.1 & 20.0 \\
\hline Pittsford Plaza & 18.5 & 2.2 & 1.2 .0 \\
\hline Eastview Mall & 41.0 & 4.7 & 11.0 \\
\hline Greece Area & 56.0 & 4.6 & 8.0 \\
\hline TOTAL & 260.5 & 31.5 & 12.0 \\
\hline
\end{tabular}

SOURCE: Larry Smith and Company Marketing.

Webster Mall Draft Environmental Impact Statement. 1980.

TABLE 6. IMPACT OF EXPRESSWAY MALL ON EXISTING REGIONAL FACILITIES.(Mi111ons) (Transfers.)

Downtown Rochester 9.0

Long Ridge/Greece Town Malls 4.8

Culver Ridge Plaza $\quad 5.0$

Eastway Plaza/Others $\quad 6.5$

TOTAL 25.3

Eastview Ma11

TOTAL $\quad \frac{8.2}{33.5}$

SOURCE: Gould Associates.

Expressway Mall Draft Environmental Impact Statement. 1980.

Tables 5 and 6 contain marketing data which estimate the transfer of commercial and retail dollars from the facilities listed. These facilities are considered major retail facllities to be effected in Monroe County. The proposed facllities are not offering or injecting any new services into the market area, but are capturing a portion of the market from other facilities. 
As a matter of orientation, Downtown Rochester is a nine (9) mile, 12 minute drive from Webster and contains an 805,000 square foot mall facility, as well as other numerous retail and comercial facilities. Eastview Mall is a 14 mile, 20 minute drive and contains an 850,000 square foot facility. Long Ridge and Greece Town Malls are a 12 mile, 17 minute drive to a 1,200,000 square foot facility. (A regional mall, the Marketplace Mall in the Town of Henrietta, is in the process of construction and will alos draw from the region's retail markets.) (See Map 2. )

The debate over the two mall proposals began in October, 1979 when both developers announced their intentions for development. Preliminary site and development plans were drawn up by each developer, setting the approval process in motion. These proposals have developeed into a political and economic "war" which has divided the twon through sometimes volatile political debates and seemingly endless litigation. Local opinion seems at a loss for comprehending the nuances of this process and where these projects are at various stages of the process.

In an attempt to discover resident reaction to this approval process and controversy, informal discussions were held with a variety of town residents during the Christmas holidays, and through a content analysis of the local newspaper, the Webster Herald. Most Websterites were we11 aware of the controversy and its length. Some people expressed a preference for one or the other proposal, but when pressed, most expressed a desire for a mall to be built and wished that the actors would move on with the process. The townspeople have generally tired of the continuing controversy "and wonder whether anyone who 
does not have a direct financial, political or locational stake in the projects is participating in the selection process." (Democrat and Chronicle 23 October 1980; Webster Herald 22 October 1980.). The "ordinary people" have been pushed aside by the monied interests who keep the debate flourishing. Throughout all of this, there is no indication that either developer has attempted to ascertain the preferences of town residents, other than the basic market research that has been conducted.

This controversial context was also fueled by the fact that six major developers had actively sought these parcels for the locar. tion of a mall since 1977. These requests have been turned down by the Town Council for a number of reasons and has caused everyone in the town to view these new proposals with a great deal of trepidation. 
CHAPTER III. New York State Environmental Quality Review Act (SEQR)

The New York State Environmental Quality Review Act, referred to hereafter as SEQR, has institutionalized a process that has had a very profound effect on the entire process of mall development approval and the final decision process of the Town of Webster. SEQR has provided a legal and procedural arena for the developers in Webster to act out their power struggle for the siting of a mall. In order to understand SEQR's effect, it is necessary to understand the act itself, its requirements, intent and performance criteria.

In 1975, the New York Legislature passed SEOR as a law that was to become effective for state agencies in 1976 and local governments in June, 1977. SEQR required that: "All state agencies, boards, public benefit corporations, authorities, commissions and their local counterparts, including local governments, to examine the environmental effects of any actions they undertake or approve." (Varley, 1977: 294; New York State Environmental Conservation Law 8-0100-0117; Sandler, 1977: 114; Weinberg, 1980: 122.)

As a means of insuring compliance with $\mathrm{SEQR}$, the statute requires an environmental impact statement (to be referred to as an EIS) for "any" action which may have a "significant" impact on the environment. The EIS msut analyze the impact of approved or proposed actions; consider reasonable alternatives; serve as a basis for administrative actions based on environmental effects of that action; full disclosure of these effects; serve as a basis for judicial review; expedite and provide for full public participation in agency decision making; and agencies must review their statutory authority, administrative regulations, policies and procedures to bring them into compliance with 
SEQR. (Varley, 1977: 294; NYECL 8-0100-0117; Weinberg, 1980: 122;

Sandler, 1977:114.)

SEQR was directly influenced by both the National Environmental Policy Act (NEPA) and the California Environmental Quality Act (CEQA). NEPA became effective on January 1, 1970 and established a national policy for protecting the environment by requiring all federal agencies to consider the environmental consequences of their actions. This was accomplished through the preparation of an EIS.

The California Environmental Quality Review Act (CEOR) was the first state law to be enacted after NEPA. CEQR provided for the same provisions as NEPA, but added two new considerations for an EIS: a description of the growth-inducing aspects of a project and a description of the measures proposed to mitigate the threatened environmental damage. (California Public Resources Code, 1976; Varley, 1977: 297.)

From 1970 to 1974, the New York State Legislature considered a ": number of proposals for environmental legislation but none were enacted. Th1s time period saw "New York lagging in the establishment of acrossthe-board procedures that would provide for a generally applicable environmental procedure and a general standard for decision making which would balance all factors." (Sandler, 1977:112.)

In 1972, the New York Department of Environmental Conservation took a first step toward a SEQR-like procedure through agency regulation. This regulation required an EIS whenever a private applicant sought a major DEC permit or approval for: air contamination source construction, public water supply approval, installation of wells of a certain depth on Long Island, stream protection, municipal waste 
disposal system construction and industrial waste disposal system construction. This proved to be an inadequate system because the establishment of the necessity for an assessment and public hearing was a discretionary decision made by the DEC Commissioner. (Sandler, 1977: 113; Varley, 1977: 298.)

In 1974, the Environmental Protection Land Development Act was introduced. This bill would have provided the Commissioner of the DEC the power to utilize full-length reporting requirements for development projects. This bill died in the New York State Senate. (Varley, 1977: 298.)

When constructing environmental legislation, it is always a challenge to define parameters in such a way as to be politically palatable for a broad range of groups. Defining a term as nebulous as "the environment" can be difficult. The 1974 SEQR legislation very broadly defines the environment to include "natural resources, objects of history and aesthetic significance, existing patterns of population concentration, distribution of growth and existing community and neighborhood character." (NYSECL 8-0105-6; Varley, 1977: 298.)

\section{OVERVIEW OF SEQR}

An evident shortcoming of $S E Q R$ is that "neither the legislation nor the implementing regulations mandate a specific procedure for determining whether the act applies to a state or local agency's action. This determination is left to the agencies themselves." (Varley, 1977: 299:) This decision is made when an agency refers to a list of exemptions compiled by the Department of Environmental Conservation. These exemptions are divided as such: 
Type I. This type usually, but not always, requires an EIS. Type I actions encompass: large scale developments; developments in critical areas such as tidal wetlands; adoption of land use plans and zoning regulations; allowing an industrial, commercial or residential use on 25 or more acres that are presently agricultural; construction of 10 or more homes in an unzoned municipality; construction of 50 or more homes if not cornected to a municipal sewer; construction of 250 or more homes in a locality of less than 150,00 people, 1000 or more homes in a locality of less than 1 million, or 2500 or more homes in a locality of more than 1 million; any action involving a physical alteration of 10 or more acres.

(Weinberg, 1980: 122; Varley, 1977: 299.)

This list is not exhaustive and lack of inclusion does not waive the requirements of SEQR.

Type II. These actions never require an EIS: construction and/or alteration of a one or two family home; the repair of existing highways that does not include new lane construction; individual setback or lot variances; and routine permit granting where there is no change in pre-existing conditions. (Varley, 1977: 299; Weinberg, $1980: 122$.

When there is no specific exemption, an agency must make a preliminary assessment as to whether an EIS is necessary. If it is determined that an EIS is unnecessary, the reasons for this decision must be made public. If an EIS is deemed necessary, the EIS process is set in motion. No project action can take place until the EIS and the SEQR processes have been fully complied with, the lead agency's procedures are followed and any applciable NEPA requirements are satisfied. (Varley, 1977: 300; NYSECL 8-0109-4.)

After the preliminary assessment determines that an EIS is necessary, a Draft Environmental Statement (DEIS) is prepared. Upon its completion, the lead agency must issue a notice of completion. This notice must contain a brief project description, an invitation for public comment and instructions for obtaining copies of the DEIS. 
Copies of the DEIS must also be filed with the local municipal clerk, the regional office of the $\mathrm{DEC}$ and its commissioner. If there is sufficient public interest, a hearing must be held in not less than 15 and not more than 60 days from the filing of the DEIS. Within 45 days of the close of the hearing, or within 60 days of the filing of the DEIS without a hearing, the final EIS must be completed. The final EIS must follow the same procedures as for the DEIS. This completes the process and only then can a project decision be made. (Varley, 1977: 300-301; NYSECL 8-0109-5)

The Environmental Impact Statement has three very important areas of concern: significant effects, timing and content. An EIS is required only for projects that will have a "significant impact". (This problem also exists with NEPA legislation.) The New York State Department of Environmental Conservation attempts to establish some criteria in its regulations, but they are brief and emphasize only absolute environmental impacts, not addressing the wide range of concern addressed in the SEQR legislation. This makes general interpretations of this "significant impact" aspect very difficult. (Varley, 1977: 302-303.)

The timing issue is critical to the process of SEQR and very important when litigation is involved. New York intended for SEQR to be implemented in the planning stage of a project. (NYSECL 8-0109-4) "This requirement exempts feasibility studies and the budgeting process but includes any related subsequent and contemporaneous effects that are part of any action. The early requirement is to avoid environmental damage and expedite administnative review." (Varley, 1977: 304.)

The most basic element of concern is the content of the EIS itself. SEQR legislation requires nine content areas for the EIS: 
1. Description of the proposal and the environmental setting;

2. The long and short-term impact of the action;

3. Any unavoldable, adverse environmental impacts and effects if the action is implemented;

4. Alternative actions;

5. Irreversable and irretrievable resource commitments;

6. Mitigating measures to minimize impacts;

7. Growth inducing aspects of the action;

8. Effects of the action on the use and conservation of energy resources;

9. Enumeration of the objections from public and agency comments. (Varley, 1977: 305-306.)

Nowhere does this legislation allow the substitution of memornada or other reports for sections of an EIS. The EIS must be written in a "brief and concise manner, capable of being read and understood by the public. Finally, the EIS must furnish a record that is detailed enough to provide an environmentally informed decision by the administrator, and to afford the public a basis for understanding and evaluating the administrator's decision." (Varley, 1977: 306.)

The content issue is basically one of full disclosure. The federal courts have ruled in NEPA cases that the amount of detail does not have to be perfect or contain every study. The EIS must be comprehensive and objective, containing more than conclusory language or simply serving as a warning to potential problems." It is anticipated that New York courts would consider these rulings when making SEQR determinations. (Varley, 1977: 306-307; Calvert Cliffs 449 F2d 1109; Sierra Club v. 
Morton 510 F2d 813; Sierra C1ub v. Froeh1ke 486 F2d 446; NRDC v. Morton 458 F2d 827.)

The reason for such a detailed review of SEQR is to understand why it is employed in the litigation of the Webster case. The challenge, as brought under SEQR, is contingent upon the concept of judicial review of an administrator's actions under the Administrative Procedures Act of New York.

Under SEQR, judiclal review examines: whether an EIS is required; public hearings; sufficiency of the EIS; substantive decisions after SEQR has been satisfied; and the sufficiency of agency prodedures to adopt and implement SEQR. (Varley, 1977: 315-316.) A shortcoming of SEQR is that it fails to provide the standards for judicial review. (The first three areas mentioned above are not specifically stated in the legislation.) This shortcoming is taken care of through Article 78 of the New York Civil Practice Law and Rules, which govern procedures.

\footnotetext{
"Unless a statute expressly prohibits judicial review, the discretionary acts of an administrator may be examined to determine if they are arbitrary and capricious." (Varley, 1977: 316; 149 NE 2d 882; 26 NE 2d 10; North American v. Murdock 190 NYS 2d 708.)
}

SEQR, like NEPA, applies to governmental activities and actions, yet the legislation has a significant effect on the private sector, especlally builders and developers. SEQR applies to the funding of projects and the issuance of permits by state and local agencies, which directly involve private parties who must comply with the regulations. (Private parties may have to provide an EIS or other reports to an agency.) (NYSECL 8-0109-3.) Even if private parties do not have to be formally involved in the process, they will as a means of pro- 
tecting their private interests in the EIS process. (Varley, 1977: $319-325$.

In the Webster case, the developers are directly involved in this process through their preparation of the EIS for each project. This protects their interests and also places them within the scrutiny of both the lead agency (Webster Town Council) and the New York State Court system. 
CHAPTER IV. A Chronology of Events.

The marketing data presented in Chapter 2 could cause some to conclude that Monroe County is saturated with shopping ma11s, shopping centers and smaller retail agglomorations. Many of the smaller and medium sized facilities have not died because of the larger facilities but have altered the services they provide to the market. What we are seeing with the Webster proposals are the last in a long line of retail developments for the county. Once a mall is constructed in Webster, any further, large scale development would be economically imprudent.

Before beginning a chronological accounting of events, it is important to trace the commercial past of Webster. The village served as the main retailing center for the Town and Village. As the Town began to expand, strip development began to occur outwardly from the Village, following Ridge Road, a major access artery. The two specific sites under consideration have long been part of the Town's development scheme for commercial expansion. The parcels are zoned for comercialddevelopment and only ineed to be rezoned for a planned commercial development (from a commercial shopping center) and are areas designated by the master plan as commercial shopping center locations.

In the mid-1970's, the Todd Mart Corporation, a local developer, attempted to win approval of a mall development proposal for the present Expressway Mal1 site. The Town Counc1l rejected this proposal even though Todd Mart had met a Council prerequisite of having a commitment from two major anchors in hand. A zone change was denied due to traffic congestion, the proximity to schools, drainage problems, 
unsuitable soils, the fact that Shipbuilders Creek (running through the site) was too envirommentally sensitive and the fact that bordering homeowners did not want the proposal located on that parcel. This rejection vame about in spite of Planning BOard approval and was upheld in a court challenge. (Webster Herald 24 December 1979.)

The mall controversy commenced in late October, 1979 when Homart announced its proposal for the Webster Mall at a press conference. Earlier in the previous week, the National Shopping Center group announced its proposal for the Expressway Mall. Each mall site is bordered by two major access arteries -- Route 104, an expressway, and Ridge Road, a major east-west artery. As mentioned previously, both of these sites were prime commercial development sites which six major developers had actively sought since 1977. According to town officials, none of these developers would make a commitment of two major tenants to the town before obtaining approval of their development scheme. This requirement was a policy established by the Town Council in 1975. (Webster Herald 24 October 1979.) This policy severly limits the type of mall development that is allowed in the town, excluding any "alternative" models and only allowing the large developers to operate.

In November of 1979 , the Planning Board granted approval of the sketch plan and preliminary plan for the Webster Mall. The Webster Town Council, in a 4-1 vote, granted peeliminary approval of the profect, determining that it met all of the town requirements and the zoning definitions of 59-19 and Articles IV and V. (See Appendix 3.)

On December 13, 1979, a 5-0 vote by the Town Council approved the intent to rezone the Webster Mall site from Commercial Shopping (CS) to 
Planned Commercial Shopping (PCS) and extended the comment period for the Draft Environmental Impact Statement (DEIS). One week later, a 4-1 vote accepted the DEIS and the Council also determined that a final impact statement was not necessary. (The DEIS was submitted to the Town Council by Homart on November 28, 1979.) (Webster Herald 25 October 1980.)

The mall announcements were made during the height of the Webster town election campaign. Until the election of November 8, 4979 , the Democrats held a one vote majority on the Council. After this at-large election, the majority shifted to the Republicans. The malls were part of the campaign's discussion but it was not a pervasive issue and not responsible for the shift in the majority. (The major issue appeared to be town management.) The Webster Mall was thus approved by a "lame duck" Council that was split along party lines. (Webster Herald 14 November 1979; 28 November 1979; 12 December 1979; 24 December 1979.)

A large number of important actors began to voice strong doubts about this process. Bruce Hegdorn felt that the present Council was ignoring the Expressway porposal. He felt that both proposals should be evaluated by the town residents through a referendum process. Supervisor-elect Kent strongly suggested that approval be delayed until after the newly elected council was seated. (Webster Herald 12 December 1979; 24 December 1979.)

For two months the approval process had been progressing on schedule and in accordance with all procedural laws. It is at this point that the process begins to bog down. Once approval was granted to the Webster Mall project group, the Expressway Mall group filed suit, claiming that the approval was illegal because the Council had not required the issuance of a final impact statement, (the Council was the designated lead agency 
or the EIS review), although the New York State Environmental Quality Review Act (SEQR) requires such a statement. (Webster Herald 25 February 1981.) New York State Supreme Court Justice David O. Boehm ruled in favor of the Expressway Mall group by overturning the Webster Mall approval and requiring the filing of a final impact statement.

This ruling placed the Expressway Mall group at a logistical advantage. They could now move their proposal through the town processes and be far ahead of the Webster group in the "race for approval". It had been conceded in the marketing studies that only one mall could be supported in this market area, thus the first mall to win approval would win this "race".

The most colorful portion of this debate began in October of 1980 , during the rezoning hearing for the Expressway Mall parcel. Previous to this hearing, the Town Council suggested that the proposal be expanded to include the anticipated uses of the parcel, that the EIS be submitted before the preliminary plat submission and that the Planning Board not act on the proposal until the Council reviewed the EIS. (This was all accomplished before this October meeting.)

At this meeting, Town Supervisor Irving Kent stated that: "With all things being equal, we want to see this mall on Hegedorn land." (Webster Herald 25 November 1980.) This caused quite a stir among the opposition, bringing claims of favoritism. When one analyzes this statement, it makes quite a deal of sense from a 1ocal perspective. The Expressway Mall group contained a number of local anchor stores commited to the development and, although Hegedorn stood to make a sizeable profit from this venture, his long standing in the community weighed heavily in his favor. 
The March meeting was turbulent, involving much bantering over the issues involved. The conflict and symbolism for the meeting was well established by the two Democrats who strode in wearing white hats. Kujawa and Murphy then left the meeting, claiming that it was illegal (after they were recorded as present and attempted to move adfournment). They were both recorded as voting, in a 3-2 party line vote, which overrode the Planning Board's recommendation that the Expressway Mall not be approved. Through its approval, the Council rezoned the land and accepted the preliminary plat and EIS.

Earlier in the same meeting, William Gray, serving as the Planning Board spokesperson, read a ruling that the Planning Board had requested from the State Controller, concerning the Board's role in the development approval process. The ruling stated that the Planning Board's approval was a prerequisite to any further Council action. If the Board rejects a PUD application, there is no state or local zoning language that allows the Council to overrule that decision, thus ending the PUD application. The only recourse for the Town was to file a lawsuit that would question the local laws under the Municipal Home Rule Law of New York State.

The Town Attorney countered that the issue was decided by the Appellate Court in Todd Mart v. Webster. In this case, the Todd Mart Corporation wanted to develop a parcel of land close to the present Expressway site. The Planning Board approved the project but the Town Council had rejected it. The Court ruled in favor of the Council, thus reducing the Planning Board's role to that of advisory. After this legal rebuttal, Mr. Gray left the meeting. The approval of the Expressway Mall project by the Council constituted the final step in the Town's review process. 
The only issue that remained was the disposition of the suits and countersuits that have been filed by the developers. (Webster Herald 22 October 1980; Democrat and Chronicle 24 October 1980.)

As a result of this meeting, the Webster Mall group filed suit in New York Superior Court in an attempt to overturn the approval of the EIS for the Expressway Mall. The suit also requested that Supervisor Kent be dismissed from the decislonmaking process. The basis for this request was an alllegation that $\mathrm{Mr}$. Kent had worked for seven years for the approval of the Expressway Mall.* Judge Boehm was also asked to rule again on the powers of the Planning Board. (Webster Herald 22 October 1980; 3 December 1980; 21 January 1981; 25 February 1981; 4 March 1981.)

* In my interview with Mr. Kent on Thursday, January 21, 1982, I inquired about this allegation. Mr. Kent explained that his backround was in banking, mortgage financing and venture capital. In the past, as a bank officer, he had contact with investors of both mall groups for other projects and transactions. As part of his personal evaluation, Mr. Kent spoke to the Supervisor for the Town of Greece concerning the responsiveness of both developers, who had built malls in that town. After this discussion, and after careful review of the financial commitment and the development proposals themselves, Mr. Kent's professional opinion was that the Expressway Mall was the most beneficial development for the Town of Webster. After giving this explanation and the allegations some careful thought, the allegations appear to be a smoke screen and last ditch effort by the Webster Mall developers to delay the Expressway project. It would have been negligent of $\mathrm{Mr}$. Kent to not serve the public interest by utilizing his backround skills and knowledge to provide a professional assessment of the situation. 
In his opinion, Jidge Boehm ruled that all procedures that were required of the Webster Town Council were followed in their approval of the Expressway Ma11 EIS. He determined that "no triable issue of fact" existed and that the Webster Mall group had no standing to sue because their interest in the case was purely economic. Boehm also refused to remove Supervisor Kent from deliberation of the proposals.

"In New York, it has been long held that the courts may not inquire into the personal motives behind enactment of legislation, unless economic involvement by the official can be proven." (Webster Herald 25 February 1981.)

Nowhere could the judge find any evidence of impropriety; the record revealed no fraud, favoritism or misconduct. (Webster Herald 25

February 1981.)

The third opinion handed down in this decision concerned the furisdiction of the Planning Board. Boehm dismissed the opinion of the State Controller, that the Council could not overrule the Planning Board. He said that the issue was decided in Todd Mart v. Webster.

Webster Associates cited New York State Town Law 274-1 (1976), which allows a town to delegate final authority to its Planning Board to approve or disapprove site plans for development. In the Todd Mart case, the town had refused to rezone a site for a shopping mall, even though the Planning Board had approved the proposal. The court ruled that the Planning Board renders an advisory opinion in the zoning and rezoning of parcels for development.

In an attempt to assuage the feelings of the Planning Board, Town Attorney Robert Teamerson stated that: "This ruling does not indicate that the function of the Planning Board is merely that of a rubber stamp. In this instance the efforts of the Planning Board were considered when the Town Council registered its decision to rezone..." (Webster Herald 25 
February 1981.) Basically, these opinions reinforce-the fact that the Town Council has jurisdiction over zoning matters as a legislative function. The Planning Board controls the actual site plan elements (soils, density, etc.) of a project. (Webster Herald 25 February 1981.)

The case dragged through the courts, with the Webster Mall group losing appeals at every turn. There was, however, a final determination of the court cases and the issues in December, 1981. Lawyers for Webster Mall Assoicates argued again that the Town Council had moved too quickly in approving the Expressway Mall plans. The suit contended that the Town Council should not have rezoned teh Expressway Mall site, since the Planning Board did not approve the preliminary plan, that the EIS did not thoroughly examine alternative sites (Webster Mall being one of those sites) and that Mr. Kent should not have voted on either proposal because of a conflict of interest. (Times Union 21 October 1981.)

Judge Richard Simon, New York State Appellate Court Judge, told the Webster Mall attorney that the case was being presented in an "either/or" posture. In fact this was not the case. The Town had the ability to accept or reject either proposal on its own merits, irrespective of the other proposal. (Times Union 21 October 1981.) The judge's ruling In this case upheld the decision rendered previously by Judge Boehm. (Democrat and Chronicle 22 October 1981; Webster Herald 23 October 1981.)

In sumnary, we have a classic development donnybrook. A number of actors, some no longer part of the process, have affected these proposals. Local officials have played out their adminstrative roles, while the developers "play for keeps" in the courts. The following chapter will analyze the role of citizens and the planning process in the development scheme in Webster. 


\section{CHAPTER V. Analysis}

The analysis of the Webster Mall controversy is for the purpose of identifying general concepts that exist in the case and their ramifications for the development process in general. Despite in-fighting by Webster town officials over site specific location, the underlying issue in this controversy relates to overall town development. Webster has been able to retain much of its rural character while planning and promoting its development. The dilemma revolves around the town's ability to accept levels of growth, while retaining the positive, "quality of life" characteristics that have attracted growth.

That the town will grow has been accepted as a given by the major1ty of Websterites. (Webster Herald 28 January 1981.) An expressway that divides the town into two sections, has brought this realization home in the form of the mall proposals. This combination of a major access artery and the mall proposals has placed a great deal of pressure on the town to grow, placing it at a development "crossroads". Townspeople and administrators have rhetorically asked how the town will plan for this surge of development. The main concern is avoiding the congestion and spraw1 that are readily evident in other county communities. (Webster Herald 29 January 1981.)

In an attempt to define the development process and its interrelationships, this analysis will employ a model that is utilized by Harvey Kaiser (1979). Kaiser's model suggests that four groups are participants in the development process --- landowners and speculators; developers, builders, bankers, et. al.; elected public officials; and non-elected public officials. The model is depicted in Figure 1 : 


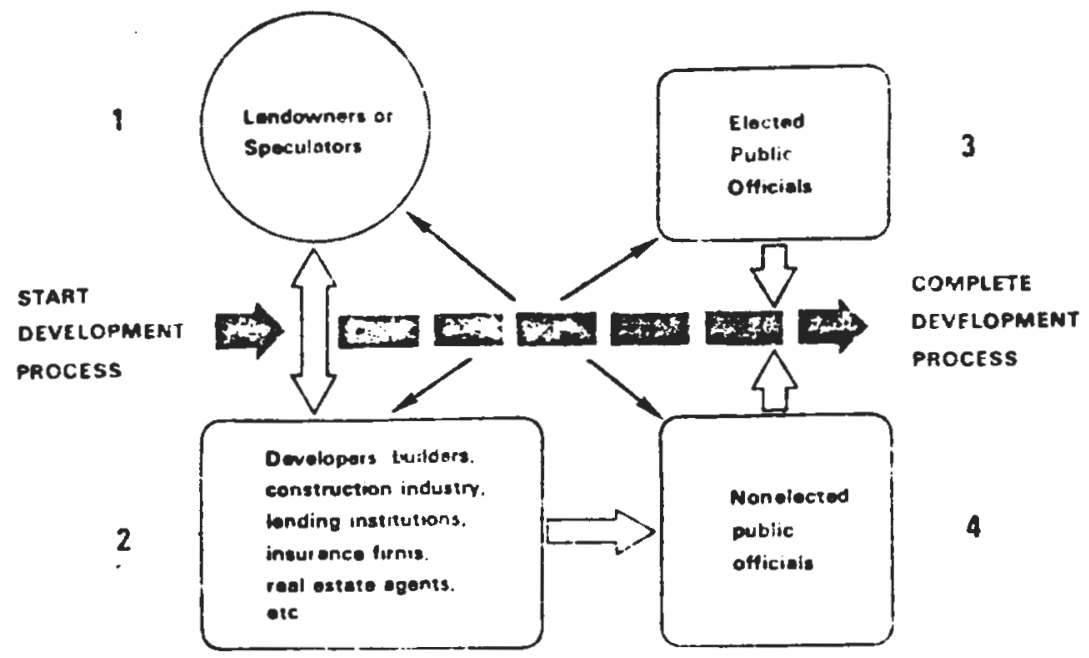

Figure 1 interactions among participants in the land-duvelopmert oricess

$$
\text { (Kaiser, 1978: 61.) }
$$

The Kaiser model depicts two modes of interaction in the land development process. Groups 1 and 2, landowners and developers interact with each other. This interaction is depicted by the large white arrows. Groups 3 and 4, elected and non-elected officials interact and are also depicted with the white arrows. Neither of these groups interact with the landowners/speculators but do interact with the developers. The thin black arrows demonstrate a minor interaction among groups 1 and 4, 2 and 3.

The pattern of interaction described is quite practical and reflective of what takes place in practice. Specualtors/landowners will interact with developers when selling land and are likely to interact with non-elected officials to assess the potential for their property within the limitations imposed by local government. Non-elected public officials are excellent functionarles for this and are actually meeting their job expectations by providing information to local citizens.

It is logical that the elected and non-elected officials will 
interact through their normal administrative duties. Developers and builderss will do the same through the permitting and approval processes that are involved in development approval.

The model can be directly applied to webster in the following manner:

1. Landowners/Speculators - Bruce Hegedorn; Webster Associates.

2. Developers, et. al. - Expressway Mall group; Webster Mall group.

3. Elected Public Officials - Town Council Members.

4. Non-Elected Public Officials - Planning Board Members; Judge

Boehm; Chamber of Commerce; other town officials.

The process described in the earlier chapter indicates that, in Webster, these parties have interacted in accordance with Kaiser's model. The glaring weakness of the process, which is articulated through this model, Is the absence of the public as a separate entity or integral part of one group.

What of the public in Webster during this controversy? It is interesting to note where the public statements have been made during this more than two year period. The majorlty of public comment can be found in two arenas -- the Webster Herald (the local weekly newspaper) and at public hearings. Comments have run the gammut from support to opposition, and include some criticism for almost everyone. Public hearings were initjally well attended and a number of citizens expressed their views on the two ma11s.

The significance of public comment, however, can be found in the timing of this input and what has not taken place during the public comment periods. If one were to superficially explore this case, public comment would appear to have taken place in the initial stages of the development process. From a legalistic perspective, this is a correct assumption, given the governmental timetables for review. From a real- 
istic perspective though, the development sites were chosen, land options purchased and the "true" development process was initiated many months prior to the time public comment and participation was mandated. This places public comment in an apparantly impotent position for alterIng the design or location of this development. The dye was already cast. It is significant to note that only once (August 13, 1981.) could a direct editorial comment by the local weekly newspaper be found. This was very unusual since the malls represent the largest single development since the Xerox Corporation located in Webster in the 1960's. A possible explanation for this could be the fact that no one publicly questioned thie wisdom of developing a regional mall, since most comments acknowledged that a mall was both necessary and inevitable. Only long after the legal battles raged and delays occurred did the Herald comment. Enthusiastic comments also suggested that Webster could become almost a new town. (Webster Herald 28 January 1981.) The new town idea saw Webster as potentially a self-contained community, with industry (Xerox and others), housing, parks, educational facilities and the like already established in the town. The establishment of a mall would solidify this perception.

Webster provides us with a classic example of the conflict in growth communities. Development issues are debated publicly and privately, Inter and intra organizationally and in the legal arena. A11 parties agree nn the premise of a rational growth policy, but this becomes a secondary concern as a result of extensive litigation and public wrangling. We1l conceived development yields to the pressure of economic and political expedienc.

The question then becomes one of who, in Kalser's model, exerts the 
most control in the land development process -- individual property owners, the community or the economic interests? Each development situation may be different, but the ensuing battle for control becomes time consuming and expensive. (kaiser, 1978: 51.) "Land use control... continues to be largely in the hands of local governments in the U.S." (Muniak, 1980: 71.), but development process control and the pressure it places on land use control, is largely in the hands of developers throughout the land. Planners who are integrally involved with this process must consider a broad range of factors. Initially, the planner must be perceptive enough to comprehend what special interests are involved in the process, who the leaders of these interests are and what relationships exist between these interests and the political decision makers. It is paramount that planners also be aware of the concerns of local restdents in relation to the development proposal (i.e. effects on the quality of life, community services and similar concerns.) Thirdly, the social climate must be assessed relative to the development proposal. Finally, local planners must attempt to anticipate the bureaucratic response to the project at state and local levels. (This is to say nothing of the important metropolitan-wide impacts that recelve amazingly little attention in this country.)

These four factors point to the central issues of development proposals -- the visible expression (the physical proposal) and the behavioral aspects of the individuals and organization (political). Physical change is the most dramatic issue affecting the lives and financial resources of actors. (Niehoff, 1966; Kaiser, 1978: 19-20.)

The political issue operates across a broad spectrum and is composed of a number of factors: 
"1. Leadership. Who leads and how that leadership is exercised. Leaders are viewed in a group context and are quickly identified by the media. The public's attitude is influenced by whether the leader is from the public or private sector.

2. The nature of the project and individual responses. Unfavorable reactions are likely to occur if the proposal and the plan for its implementation are unclear.

3. Timing. If a community is not informed of a development proposal until the project is well along, a developer can be accused of trying to sneak something over on the town. If a community is advised well in advance of a proposal, many groups can mobilize. Developers accuse these groups of delay tactics.

4. Individual participation is predicated on a person's attitude toward a development. This participation is tempered by an individual's political awareness, sense of importance and alienation, knowledge of the proposal, the political process and, most importantly, an individual's economic stake in the proposal."

(Kaiser, 1978: 60; Davies, 1960; Wilson, 1977.)

Kaiser's model is an accurate portrayal of interaction within the development process. The fact that the public-at-large has not been included is no accident. The concerns of the public are seen as more of a nuisance to the development process than an integral, positive aspect of that process. The contention from this corner is that since there are so many avenues open to monied interests which allow them to diffuse public opinion, the public is viewed as another "cost of doing business" as opposed to a partner in that process. The avenues open to public officials for the same purposes are limited but still exist (i.e the manner in which meetings are run, scheduling, speed of the approval process, etc). A closer analysis of the Webster controversy will bear 
this contention out.

In Webster, the question of the "public interest" has been decided by the town's madter plan, which calls for a regional mall in either location. The town, its officials and citizens have decided what is in their interest. This has been championed by both developers throughout this controversy. The welfare of the community is assessed within the parameters of a shopping mall. Since the public interest question was decided previous to the introduction of these proposals, the implementation process (development approval) simply draws analytic attention.

The general public in Webster has a number of outlets through which they can theoretically affect the development process -- planning board meetings, Town Council public hearings, local pressure groups/coalitions, informal contact with local elected and non-elected officials and the courts. Each of these forums provides only for reaction to a proposal, providing no avenues in the formulation of a development proposal.

Planning Board meetings are accessible to the public, but provide the least amount of leverage since the Board's role has been legally defined as advisory to the Town Council. The public has little control over this non-elected advisory board. Town Council meetings provide a more meaningful source of input for the public since there is approval control for the development at this step. The Town Council is the "ultimate authority" but this does not guarentee that the Council will actively seek or act in accordance with the opinions expressed by only those citizens who speak out at meetings.

Local pressure groups and coalitions may be the most direct manner to effect a development proposal, either on their own or through the courts. Modifications or total stoppages have been accomplished through these types of groups. However, this has not been the case in 
Webster because there are two proposals. As a result, local groups have sided for one or the other proposal and have removed any appearance of impartial judgement of the proposals in light of the public good. The Webster citizen groups have allied themselves so closely with one or the other proposal that they are, in fact, acting as surrogates for the developers in accomplishing much of the groundwork for local acceptance of their specific proposal.

Informal contact with elected and non-elected officials is a reality in Webster, since its population is relatively small. The quality of contact is directly proportional to a citizen's influence within a community. Thus basiness leaders will have a greater influence than the occassional homeowner. This informal contact with citizens or businessmen is not a practice openly promoted by politicians because of the obvious conflict of interest potential. Again this forum is a mismatch, with the developer holding the upper hand in Webster. The malls are proposed for sites that are compatible with the master plan. The informal contact would not change anything that is essential to the proposals.

A court challenge can prove to be successful for citizen input, if they can prove standing and probable cause: This is usually an expensive and time consuming process which not all citizens can pursue. The lawsuits filed in Webster have not been filed by the citizens, but rather by the developers. The election process can be effective only in removing an official after the fact. It has no direct influence on a development proposal at hand, if the controversy is not "hot" and in the limelight. 
As we see, the citizens of Webster have little effective, formalized input for the mall siting decision. Rondinelli (1975) and Anderson (1976) suggest that "investment in a facility is made within the context of a centralized decision making process. This system is made operational through accepted discretionary powers exercised by local legislators." (Rondinelli, 1975: 4.) The interpretation being that developers and legislators accept this context (minus direct citizen input) as a "normal" aspect of the game.

Since the public is on the "outside looking in" during the development process, who, if anyone, attempts to project the public opinion and inject that opinion into the debate. Present economic realities have transformed administrative officials into tax-base hungry "magnets", who are more fiscal mercantilists than administrators. (Beeman, 1969: 5.) This situation makes it extremely difficult for non-elected officials, who must answer to the adminstrators, to work directly and actively on behalf of the public interest. In spite of the pressure, this task must be the responsibility of the planner. The planner must take this responsibility through the political process in order to be effective in the development process.

The planner must be aware that " 1 and conversion is much more an ad hoc process than the profession had previously admitted.... It is inherently a satisficing rather than optimizing process." (McBride and Clawson, 1970; 22.) Policies and decisions affecting land use policies are often made simultaneously and since land use is contingent upon policies, then the planner must be fully aware of who the parties involved are and what they represent. Policy becomes what the government does rather than what they say they will do (RIder, 1980: 594.) which is 
directly affected by pressure groups. (Dah1 in Freiden and Morris, 1968: 225.)

Ad hoc land development is essentially a description of a political process, almost Identical to that described in Chapter One of this paper. The planner is confined by an imperfect system that assumes democratic action but is influenced by pressure groups elites. The pressure groups in the development process are described here as elites because of their economic influence. These elites are highly capitalized and exert a disproportionate influence on the development process. The measuring of this elite influence can be broken down into four areas: 1) the distribution of influence, which is pervasive; 2) the pattern of influence, which is project specific and economic; 3) the extent of conflict and cohesiveness among the elite, in which we see cohesiveness of purpose and conflict when competing for the same market; 4) changes in the system, which may or may not occur depending upon the disposition of the community toward development. (Dahl in Freiden and Morris, 1968: 226.)

The influence of the economic elites is exercised through a use and control of money and credit, control over jobs, control of information and its distribution, knowledge and expertness and the social standing of the economic influentials. (Dahl in Freiden and Morris, 1968: 231.) Possession of these "tools" of influence does not guarentee resulting influence unless utilized to thetr fullest. Possession and utilization of influence, in conjunction with a sitaution that causes planners to react to development proposals, serve to place planners at a distinct disadvantage in the development process.

A more particularized view of the general planning process in 
Webster, uncovers a critical situation for a growth community, and an especially critical situation for a community that is accepting a development as consequential as a regional mall. Webster does not have a town planner. Like a large number of smaller communities which border metropolitan areas, a planner has not been hired and is not seen as a necessity with the presence of the Monroe County Department of Planning. The Town relies on technical assistance from the County planners working in conjunction with the Town Planning Board. While the County planning staff supplies top quality technical assistance, a number of problems exist with this set up.

County planners may be able to keep abreast of Town issues but this will be on a secondary basis. Since they are not part of the community, nor part of the local administrative structure, the ability to review day-to-day operations and make a highly informed assessment of a complex process is next to impossible. County planners will only provide assessments when requested by the town, unless an extraordinary situation exists. This is understandable since "butting in" is not conducive to maintaining a good relationship with the same local officials who determine local contributions to County government, which pays the salaries of the planners. The planners are forced to operate as technicians only, avoiding any unpopular statements or assessments that might offend a political actor, and failing to become involved in a truly broad policy advisory role. This situation also removes the planners from any politically sensitive interaction which is essential to legitimizing the role of the planner and the technical tasks that are undertaken. Sensitive to this watered down assessment process and the absence of a day-to-day planning "department", developers have been quick to 
provide any munber of experts and accompanying information, which places more pressure on those responsible for assessing this information. This analysis would be remiss if it did not address the issue which has caused the most consternation in Webster -- time delays. As mentioned in previous chapters, popular opinion in Webster places much of the blame on town administrators. (This assessment is a result of a content analysis of letters to the editor to the Webster Herald and informal questionIng by the author.) The fear that one of the developers would move the project to neighboring Wayne County, thereby forfeiting the tax revenue, increased the perception that local officials were dragging their feet. Some time was necessary for the preparation, acceptance and review of the draft and final EIS, but the town acted well within the mandated time frames during the review period. If there was any excessive delay, it came early on when the Town Council accepted a preliminary EIS for Webster Mall and did not require a final EIS. (See Chapter IV.) Delays resulted from the filing of lawsuits and legal briefs and the court process. Other than this situation, further delays have resulted from the extensive 1itigation initiated by teh developers. The majority of this litigation has emanated from the Webster Mall developers in their attempt to find fault with the Expressway development proposal and the behavior of local offictals. The litigation has extended the process for over two years and, while caused by the developers, the public's perceprtion of who is causing the delay seems to have changed very little. There are two reasons that appear to explaing this attitude of local residents. First of all, the local forum for all of the debates takes place in town facilities, at meetings presided over by town officials who carp at each other for political "point making" at these meetings 
and in the newspapers. This lends creedance to the perception that town officials are running and ruining the process. The influentials (two main developers) have maintained a relatively low profile throughout. Presentations have been made, experts have been called and lawsuits filed but the link of total responsibility is missing. The local paper, the only real information outlet, has downplayed the developers' role. Local citizens know that each developer wants their own site to be the location of the mall, but fail to transmit this to an understanding of responsibility for the delays. The scenario has been acted out by local surrogates (town officlals, citizen groups) which has allowed the developers to avoid consistent public exposure. This entire situation adds a great deal of saliency to the Hunter/Mills analysis offered in Chapter I, which claims that an economic elite, in fact, does control and influence major decisions in a community. 
CHAPTER VI. Conclusion.

Webster, New York is the rule rather than the exception to: the land development process. Ad hoc land development will not be radically altered by an impotent public and, by necessity, is reacted to and acted upon by local administrators who lack the one local technician who could offer a synthesis of local values, technical assessment and comprehensive review of the development proposals. Unfortunately, everyone feels that they can "plan" but not everyone has the tools to plan or the ability to implement the planning based decisions. The author doubts that the town's administrators nor residents understand the function of a planner.

This is not to suggest that a planner is the savior for a growth community, but the broad range of skills and resources should be an integral part of the administration of any community, regardless of their position on the growth-decline spectrum. The Monroe County Planning Department makes the best of a situation that is politically sensitive. However, there are a number of gaps that occur in such a process, for which the Department is not responsible.

The development process is an ad hoc process which is controlled by powerful economic interests competing for a particular market. The planning process becomes reactive rather than leading, and places local officials in a defensive posture which is difficult to extract themselves from. The ability to alter the public's perception of "ineffectiveness" becomes a nearly impossible task.

In Webster, the toon was fortunate that the development proposal corresponded to the master plan. Any number of cases can be cited in which the master plan has been disregarded when a final development 
decision was made. Until recently, there has been little legal impediment to this situation occurring any number of times. Recently though, some courts have recognized the master plan as a legal document. This can only support the planning process in the future and better define the development process locally.

While this may appear to be a cynical view of the process, there is a glimmer of hope. To remedy these problems a number of tasks msut be undertaken by planning professionals, the main one being public relations. Local planning organizations must make the public aware of what planners do, why and how that is beneficial to a community. This articulation must be combined with political action to make legislators sensitive to the planning "agenda".

Locally, planners must evolve from the technocratic mold to a diverse professional who operates within the entire, broad spectrum of local affairs, from politics through implementation and analysis. The local planner must educate the public. Visibility makes townspeople cognizant of the profession and its purpose. This is the only manner in which to gain acceptance at the local level for the planning process.

In the final analysis, the planning process will survive if planning establishes itself within the legal framework of land use (i.e. master plan as a legal document), planning establishes a working relationship with developers and the process is an integral part of active, on-going local policy making. This is the only means by which the profession can make an in-roads on the pervasive power developers hold over the land development process. 
In his article, Muniak (1980) discusses the land development process through an analysis of the effects of local Conservation Commisions on the land development process in Massachusetts.

Superimposing narrow focused development organizations over the existing, insitutitonalized planning framework, may drastically upset... land use planning. It is out of line with the costly investment of earlier efforts by the federal government to build a balanced planning capacity within local governments. The conflict and confusion... might well contribute to a public loss of confidence in local government's ability to manage this process." (Muniak, 1980: 73.)

While this is a paraphrase of Muniak's quote, this applies quite succinctly to land development in general. Local governments cannot afford to let the narrow interests of developers rule land development and ruin a federal effort to expand the planning capabilities of local governments. In some places around the country, and in Rhode Island, this has occurred and the public has, in fact, lost confidence in the local government's ability to manage the land development process. 
A Guide to the Planning and Zoning Laws of New York State, Revised January, 1981. New York State Department of State. Division of Legal Services. Albany, New York.

Anderson, J.E. Public Policymaking. New York: Praeger. 1976.

Arkes, Hadley. The Philosopher in the City: The Moral Dimensions of Urban Politics. Princeton, New Jersey: Princeton University Press. 1981.

Beeman, William J. The Property Tax and the Spatial Pattern of Growth in Urban Areas. Research Monograph \#16. Washington, D.C.: Urban Insittute. 1969.

Berry, Brian. "The Retail Component of the Urban Model." Journal of the American Institute of Planners. May, 1965.

Birch, David L. The Economic Future of the City and Suburb. New York: Committee for Economic Development. 1970.

Bolan, Richard S. "The Practitioner as Theorist: The Phenomenology of the Professional Episode." Journal of the American Planning Association. $46 \mathrm{July}, 1980: 261-274$.

Bryson, John M. and Delbecq, Andre L. "A Contingent Approach to Startegy and Tactics in Project Planning." Journal of the American Planning Association. 45 April, 1979: 167-179.

California Public Resources Code 21000. Deering. 1976.

Catalano, Richard. "Local Government and the Environmental Impact Report." Urban Law. 8 Spring, 1976: 367-374; 9 Winter, 1977: 195-206.

- "Local Government Response to State Environmental Impact Assessment Requirements." Environmental Law Reporter.

7 Fall, 1976: 25-50.

Code of Federal Regulations. $40: 1500.6 .1976$.

Cohen, S.B. and Lewis, G.K. "Form and Function in the Geography of Retailing." Economic Geography. 43 January, 1967: 1.

Cohen, Yehoshua S. Diffusion of an Innovation in an Urban System: The Spread of Planned Regional Shopping Centers in the U.S.: 1949-1968. University of Chicago Press. 1972.

Cupps, Stephen. "Emerging Problems of Citizen Participation." Public Administration Review. September/October: 478-487. 
Dah1, Robert. Who Governs. New Haven: Yale University Press. 1961.

Environmental Law Symposium. Santa Clara Law Review. 19 Summer, 1979: 513-680.

Frieden, Bernard and Morris, Robert. Ed. Urban Planning and Social Policy. New York: Basic Books, Inc. 1968.

Herr, Paul. "Local Government Competition for Business Activity: An Urban Case Study." The Professional Geographer. 31 August, 1979: 3.

Hunter, Floyd. Community Power Structure. Chapel Hill: University of North Carolina Press. 1953.

Kaiser, Harvey H. The Building of Cities: Development and Conflict. Ithica, New York: Cornel1 University Press. 1978.

Kaminsky, Jacob. How To Evaluate a Development Proposal in Your Community. Reston, Virginia: Environmental Press. 1979.

Legislative History of SEQR. Standing Committee on Environmental Conservation. New York State Assembly. 1975.

Levin, Charles; Legler, John B.; and Shapiro, Perry. An Analytical Framework for Regional Development Policy. Boston: MIT Press. 1970.

Lindbloom, Charles E. The Policymaking Process. New Jersey: Prentice Hall. 1980.

Manes, Sidney. "Alice In the Wonderland of SEQR." New York State Bar Journal. 52 Fall, 1980: 115-119.

McBride, George and Clawson, Marion. "Negotiation and Land Conversion." Journal of the American Institute of Planners. January, 1970.

Meler, Richard L. Planning For An Urban World. MIT Press. 1974.

Micahel, A; Fitzgerald, R.; and Durant, R. "Citizen Evaluations and Urban Management: Service Delivery in an Era of Protest." Policy Studies Journal. 3 Winter, 1973: 85-92.

Muniak, Dennis. "Policy Conflict in Local Government: Environmental vs. Planning Interests." Planning and Administration. 8, \#1. Spring, 1980.

National Model Cities Community Development Director's Association. A Guide to Local Economic Development Planning and Implementation. Washongton, D.C. 1976.

New York State Environmental Conservation Law. McKinney. *-0100-0117. 1976. 
Nichols, Rosemary and Robinson, Nicholas A. "A Primer on New York's Revolutionized Environmental Laws, Parts I and II." New York State Bar Journal. 49 January/February, 1977: 41-47; $111+$.

Ostrom, Elinor. "The Needs for Multiple Indicators in Meeting the Output of Public Agencies." Policy Studies Journal. 3 Winter, 1973: 85-92.

Redstone, Louis G. New Dimensions in Shopping Centers and Stores. New York: McGraw Hill. 1973.

Rider, B. Robert. "Decentralizing Land Use Decisions." Public Administration Review. November/December, 1980: 594-602.

Rochester Democrat and Chronicle. 23 October 1980. - 24 October 1980. - 27 January 1981.

Rondine11i, Dennis A. Urban and Regional Development Planning. Ithica; New York: Corne11 University Press. 1975.

Rothblatt, Donald N. National Policy for Urban and Regional Development. Lexington, Massachusetts: Lexington Books. 1974.

Sanders, Irwin T. The Community: An Introduction to a Soctal System. New York: Ronald Press, Co. 1958.

Sandler, Ross. "New York State Environmental Qhality Review Act." New York State Bar Journal. 49 Fall, 1977: 110+.

Schmore, Leo F. "The Soico-Economic Status of Cities and Suburbs." American Sociological Review. XXVIII. 1963.

Simmons, James. The Changing Pattern of Retail Location. University of Chicago Press. 1964.

Stemleib, George and Hughes, James. Shopping Centers: U.S.A. Rutgers Center for Urban Policy Research. New Brunswick, New Jersey. 1981.

Stewart, Thomas R. and Gelbard, Linda. "Analysis of Judgement Policy: A New Approach for Citizen PArticipation in Planning." Journal of the American Institute of Planners. January, 1976.

Straniere, Robert A. and Krause, Kathryn E. "Land Use in New York: An Evaluation of Policy and Performance." Empire State Reporter.

February/March, 1975 . 
The Dollars and Cents of Shopping Centers. Urban Land Institute. Washington, D.C. 1966.

The Future Pattern of Shopping. National Economic Development Office. London. 1971.

Varley, Kenneth. "New York Environmental Quality Review Act: An Overview and Analysis." Albany Law Review. 41 1977: 293-328.

Warren, Roland. The Community in America. Chicago: Rand McNally. 1978.

Webster Herald. 22 October 1980.

- 25 November 1980.

- 3 December 1980.

- 17 December 1980.

- 21 January 1981.

- 28 January 1981.

- 25 February 1981.

- 4 March 1981.

- 11 March 1981.

- 15 April 1981.

.. 29 April 1981.

- 17 June 1981.

- 3 June 1981.

- 1 July 1981.

- 11 August 1981.

- 21 August 1981.

- 2 September 1981.

- 19 October 1981.

- 21 October 1981. 
Weinberg, Phillip. "What Every Real Estate Lawyer Should Know About New York State's SEQR." New York State Bar Journal. 52 Fall, 1980: 122-128.

White, Louise. "Approaches to Land Use Policy." Journal of the American Planning Assoication. 
APPENDIX 1. MAPS 
MAP 2 .

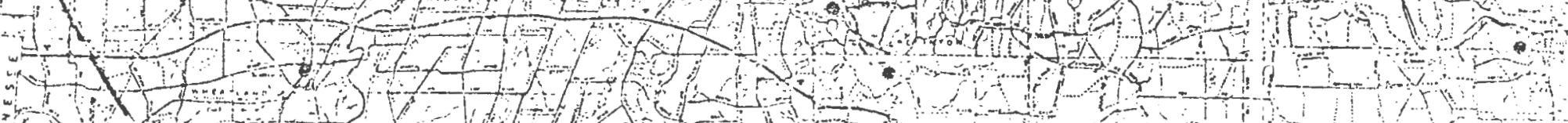

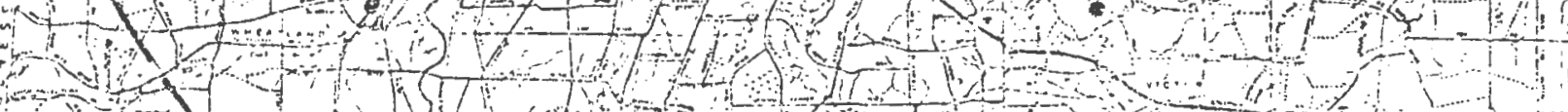

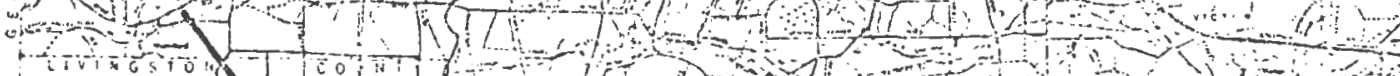
$+$

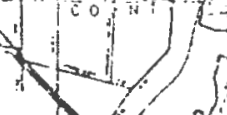

(N) 
MAP 3. WEBSTER MALL SITE

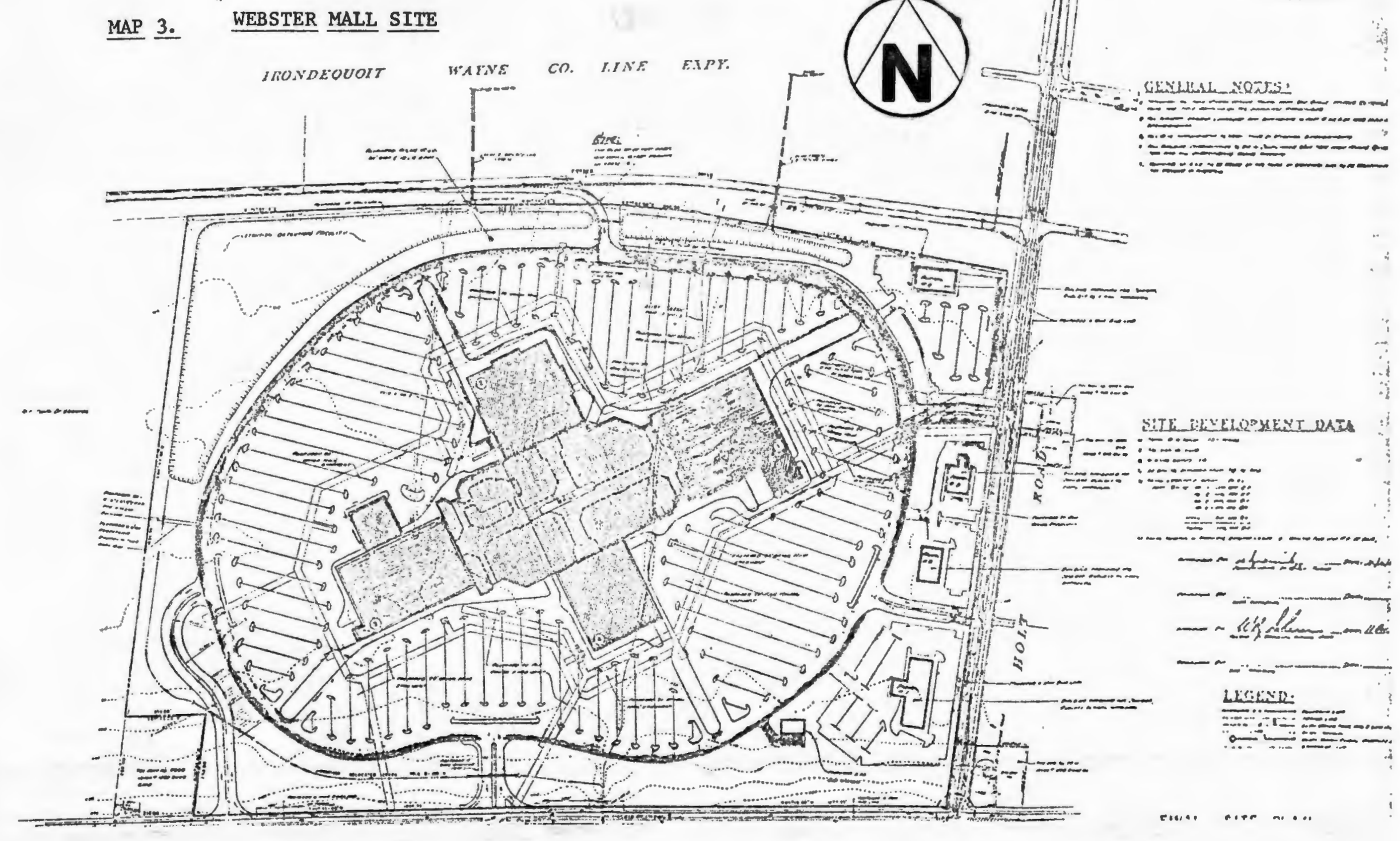







TOWN OF WIBSTER

Map 5. ZONING MAP

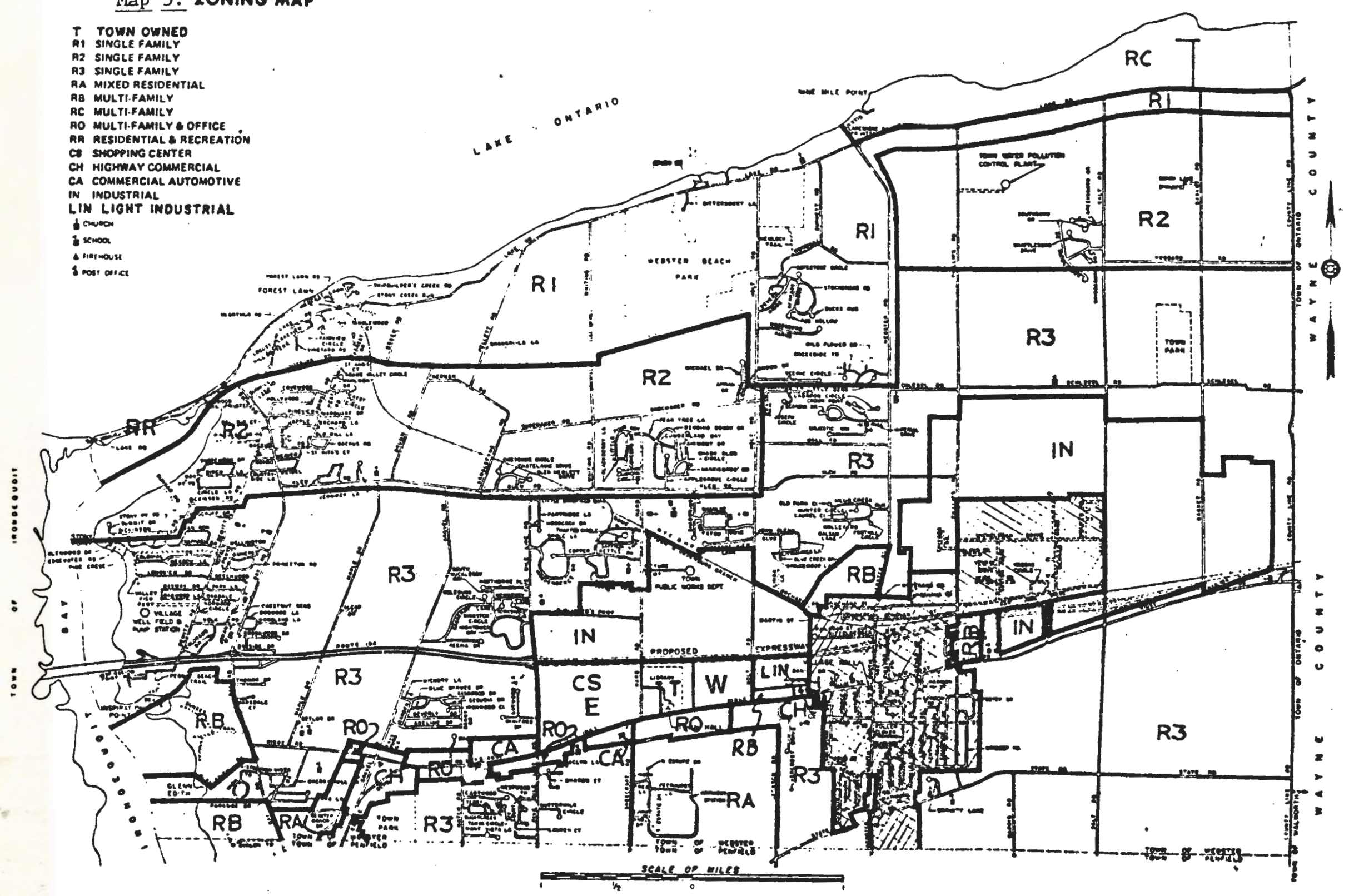


Map 6. GENERAL DEVELOPMENT PLAN

MONROE COUNTY NEW YORK STATE

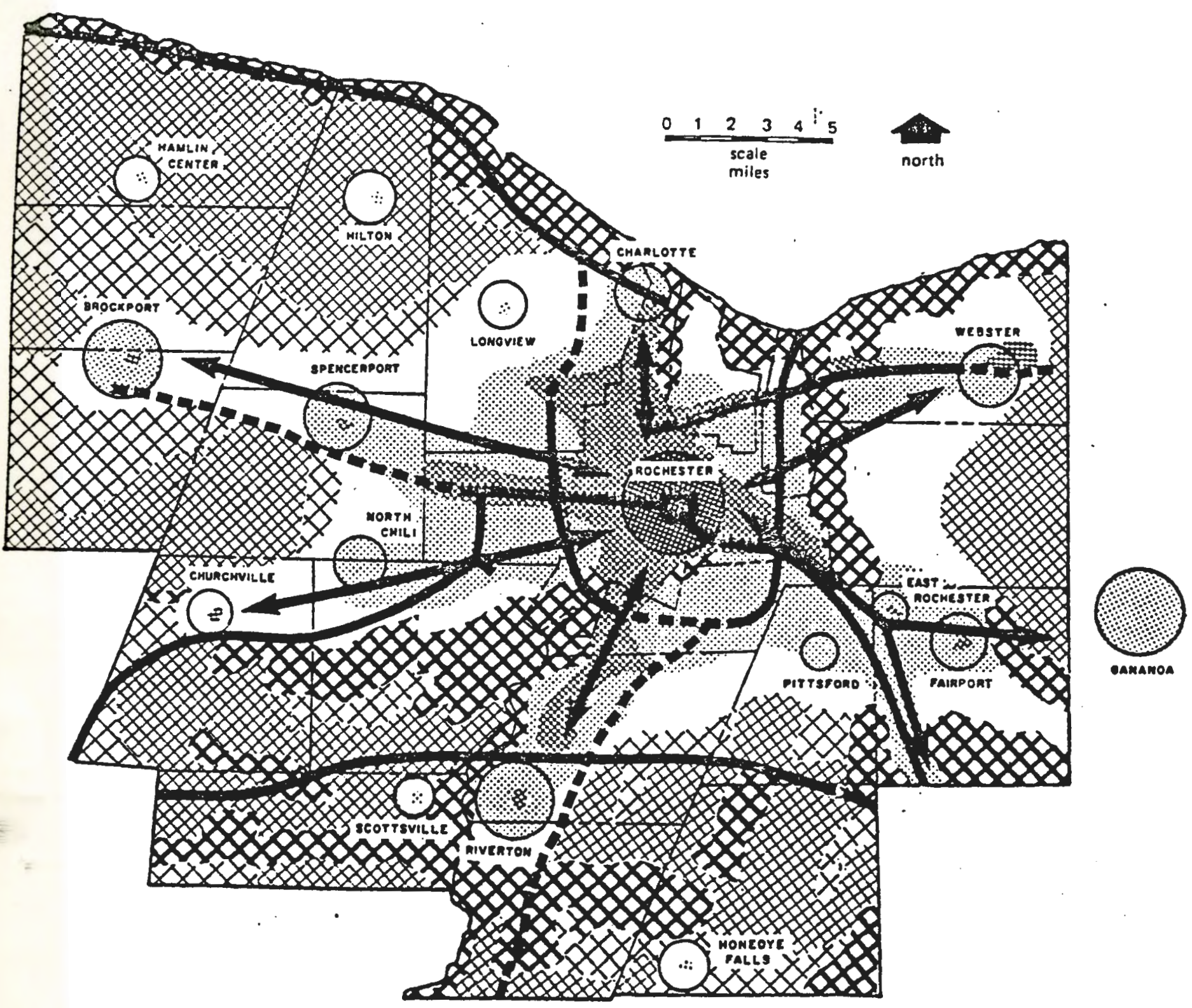

LEGEND

Metropolitan Core Development

High-intensity Urban

?adium-intensity Urban

$\square$ Low-intensity Urban

QXX Rural Nonfarm

Viable Farmland

88 Major Resource Protection Ares

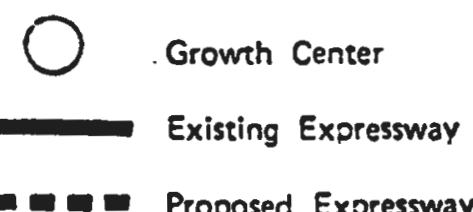

- - Droposed Expressway

$\longrightarrow$ Major Public Transportation Improvements

- 
APPENDIX 2. New York State Environmental Quality

Review Act (SEQR). 


\section{ENVIRONMENTAL CONSERVATION LAW $§ 8-0101$}

\section{ARTICLE VI-IMPIEMENTATION OF ENVIRONMENTAI، QUALITY BOND ACT OF 1972}

1972 Audition to Source I.Aw

Article VI of the Environmental Conservation Law of 1970, L.1970, c. 140, which implemented the Entrironmental Quality Bond Act of 1972, was repealed by L..1973, c. 400, \$ 91, eff. June 5, 1973. The substance of such Article VI, consisting of sections 201 to 205,220 to 222,240 to 243,260 to 265,280 to 283 , and 290 to 292, was incorporated into the Environmental Conservation Law of 1972, L..1972, c. 664, $\$ 2$, by L.1973, c. $400, \$ 90$, eff. June 5, 1973, according to the following table:

Former Enironmental

Recodified Environmental

Conservation Lav Sections Conseriation Law Sections

202

$51-0101$

51-0103

203

204

51-0105

51-0107

205

51-0109

220

$51-0301$

221

51-0.303

222

$51-0305$

240

51-0501

241

51-0503

242

$51-0.505$

243

51-050i

51-0701

261

51-0703

51-0705

262

263

264

265

280

281

282

283

290

51-0709

51-0711

51-0713

51-0901

$51-0903$

51-0905

51-0907

51-1101

51-1103

51-1105

\section{ARTICLE 8-ENVIRONMENTAL QUALITY REVIEW [NEW]}

Sec.

8-0101. Purpose.

8-0103. J egislative findings and declaration.

8-0105. Definitions.

8-0107. Ageney implementation.

8-0109. Preparation of environmental impact statement.

8-0111. Coordination of reporting; limitations; lead agency.

8-0113. Rules and regulations.

8-0115. Severability.

8-0117. Phased implementation.

\section{8-0101. Purpose}

It is the purpose of this act to declare a state policy which will en. courage produrtive and enjoyable harmony between man and his environment; to promote efforts which will prevent or eliminate damage to the enviroument and enhance human and community resources; and to en- 
Sept. 1, 1976, pursuant to effective c. 612,8 ; a mended L.1976, c. $22 x$,
f.

\section{Law Reviow Commentartes}

A primer on New York's revolu tionized enviroumental law. 40 N.Y. .B.J. 41, 111 (1977).

or water 's SEQR-its fmportance for water pollution control. 50 N.Y. B.J. 572.

State Environinental Quality Re Vie.t Act. 49 X.Y.S.B.J. 110 (1977) Library References

Lealth and Euvironment 25.5 .

Index to Note:
Generally 2
Construction $1 / 2$
Purpose 1
Statement of environmental impact
3

\section{$\int^{2}$ 2. Construction}

th. light of renconst be construed in of endulitions impons and any limitatious tis governed by "reasopubleups must if rher yre to survive judicial revies Tunn of llenriottas s. Irepartment of

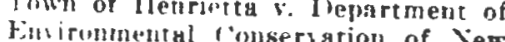
lork, 14N, if A.I S.2i 215, 430 X.Y.S. $2 d+11$.

\section{Purpose}

Cimeral substantive molicy of this arricle is flexible one, which leaves ron!!n for respmilhte exerrise of dis. retion and hows nut require particula $r$ substantise results in particular irvilimativ instanees: it loes, how Ner. make environmental protection iart of the mandute of every state abroty atul departunent. Toun of Hurieltas s. lewartment of Fniron m.ntul conservation of cow lork,

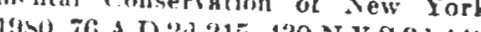
Eivirumul.s. 215,430 N.Y.S.2d 4.40. tion of tion of city director of planuing and zoning ameniment of list of ordinance, which would sild to

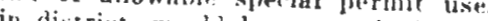

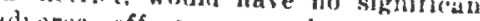

\& 8-0103. Legislative findings and declaration

The legislature finds and declares that:

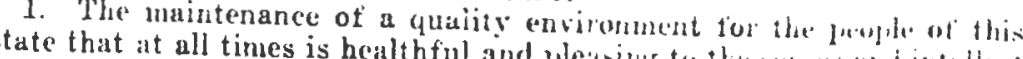

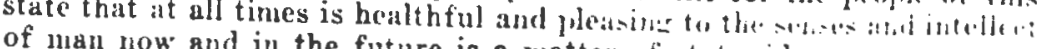
of man now and in the future is a matter of statewis? concenn.

2. Every citizen has responsibility to contribute to the fartan and eubancement of the quality of the chvironment.

ese ronmental impact study would not be required, was not premature, inas be required on applical review might permit. Kravetz $\mathrm{v}$. Plen for 1870,10 Mfiec.2d 622, 424 N.Y.S.2d 312.

Section 8-0101 to 8-0115 were in tonded to permit state and loca agencies to intelligently assess and with rant wherations in determining wiprove project or Hetivity should be consered or undertaken. Tuxedo Tonservation and Taxplayers Axs'n $y$. 6 Mind of Town of Tuxeylo, 1978 , firmel 60 A.D.2d 320 . 118 des, afQ3x.

\section{Generally}

This artiraln reduires decision maker cot bance henefirs of propused projmental rink its unatoitable euvironappras rink in determining whether to approve the projert. Town of ITrnri. ('on

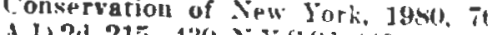
This 215,430 .......2 440 This article foes not rlange jurichetween or amon's state ur lo. cal ageacies; and rekulitions phere

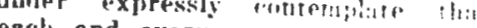
ath and every akency molsinus it

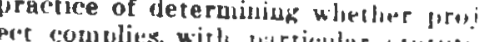
it administers. Town of poushasen

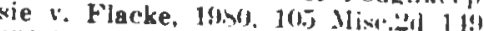

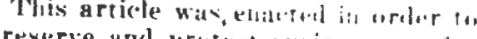

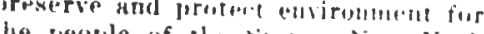
he people of the stato. Now lork

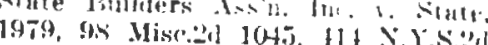

tatement of environmental im.

mblent of this arficle is that a...r? the commes withis state tild $n$ it conservarion of the siate at itite

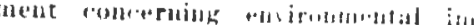

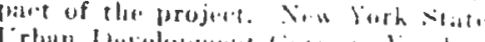

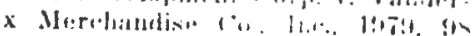

of the state. 


\section{Standing}

Anyone who can how adverse enVironmental impact causing bim injury as result of egency action has standing to bring action challenging of Webeter, 1980, 104 Miec.2d 852 429 N.Y.S.2d 811.

Reeident homeowner: living adjacent to or vers near subject property had atanding to bring action geeking to invalidate rezoning by town board which created planned shopping commercial district within existing commercial shopping center district, even though homeowners were allegedly primarily motivated by economic congiderations because homeopners' interest iell within zone of interest protect atatutes involved, where they would

pacts, and stated purpose of this article was to insure that duc consideration was given to preventing environ mental damage. Id.

Mére fact that landowner-Jocal business operator had large economic con. cerns unrelated to environmental of fects of proposed development wa not enough, in and of iteelf, to deny standing to bring action secking to invalidate rezoning by town board which created planned shopping commercial district within existing commercial shopping center district, where landowner-local business operator could show same probability of enviroumenta) danage as had other petitioners, who were resilent homeoxners living adjacent to or very near suhject property. Id.

\section{8-0105. Definitions}

Unless the context otherwise requires, the definitions in this section shall govern the construction of the following terus as used in this article:

1. "State agency" means any state department, agency, board, publir benefit corporation, public authority or commission.

2. "Local agency" means any local agency, board, district, rommission or governing body, including any city, county, and other jolitical subdivision of the state.

3. "Agency" means any state or local agency.

4. "Actious" include

(i) projects or activities directly undertaken by any agency; or projects or activities supported in whole or part through contracts, grants, subsidies, loans, or other forms of funding assistance from one or more ayencies; or projects or activities involving the issuance to a person of a lease, permit, license, certiticate or other entitlement. ior use or permission to act by one or more agencies;

(ii) policy, regulations, and procedure-naking.

5. "Aetions" do not include:

(i) enforcement proeeedings or the exereise of prosecutorial discretion in determining whether or not to institute such proceeding's;

(ii) official acts of a ministerial nature, involving no exercise of discretion;

(iii) maintenance or repuir involving no substantial changes in existing structure or facility.

6. "Environment" means the physical conditions which will be affected by a proposed action, including land, sir, water, minerals, flora, fauna, noise, objects of historic or acothetic sirnificance, existing putterns of population concentration, distribution, or growth, and exiating community or neighborhood character.

7. "Environmental impret statement" means a detailed statement setting forth the matters specified in section 8-0109 of this article. It includes any comments on a draft environmental statement which are received pursuant to section 8-0109 of this article, and the agenry's reswotse to such conments. to thr evtent that whe comments raise issurs statement prepared pursuant to section $\gamma-0109$ of this article. Added L.1975, c. 612, §1; amended L.1976, c. 228 , § 1; L.1977, c. 252 , $\S 2$.

1977 Amendment Subul. 4, par. (i). L.1877, 2 252, 2 , eff. June 10 1877, inserted "projects or activitien" preceding the word "supported" and
"involving".

1976 Amsndment. IL1976, c. 228 1. eff. May 28, 1976, redegignated former ubd. 1 as subds. 1 to 3 , suh stituted the specific terms "State agency" "Lacal arorry" and "Agen" for the vincle term "Agency", therin and resignated former to 8 a 8 , respectively. Effectlvo Date Section effectiv. Eit 1976 pursuant to 1975 c. 212 amended L 1976 , c. 228 4.

\section{Index to Notes}

Actions 4

Declaration of Intent to rezone 6 Iadustrial development agency I Projects or activities Involving per. wit 5

Projects or activities within article 3 Urban development corporation 2

1. Industrial development agency The Auburn Industrial Develonment Autbority is a "State akency" ani was required to comply with the first step of tlie phased implementation of the State Eovirnnmental Qunlity L. view Act (AFQR) on Siptember 1 , 1976. 1976, Op.Atty.rien. (Inf.) Zut. 2. Urban development corporation New York State Lrban L.velopment Corpuration, designaterl bis leg. islature to subervise state's partial funding of donsed stadium facitiog for unicersity, oud city planning combuis. aniou were "useacies" cocertied by this article and construction if this article and construction" sub. O. M. E Y Yew Lork Stute I'rbial O. M. E.

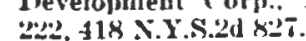

3. Projects or activities within artiProjects or activities within arti-

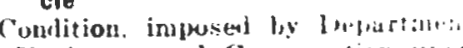
of Finvironmental Conservation upon

8 8-0107. Agency implementation

All agencies shall review their present statutory anthority, adminis trative remulations, and current policies and procedures for the purpose

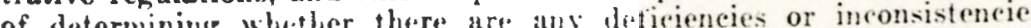

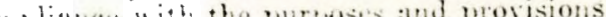

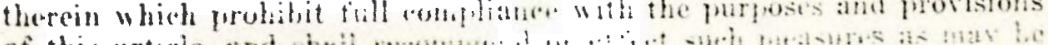

developers of regional shopping mall, regulating-number of parking spaces ich was in turn directly related to air quality and therefore valid concern Cor Department of vironmental Conservation of New York, 2 .

State Enviroumental Quality Review Act, this article, applied to constructim of domed facility at univerState Urban Development Corp. 1979,69 A.D.2d 222, 418 N.Y.S.2d $8: 2$

4. Actions

Application to amend text of zoning ordinance is an "action" subject to Envirolumental Conservation Law and reguldrions adopted thereunder. 6.2.2 t24 N.Y.S.2d 312

5. Projects or activities involving permit

County's issuance of permit required for village's spraving for mosquito cuntrol was a turely ministerial act and thus exempt from the require ment of the statutes governing enrironmental quality review. 356, t2 X.Y.eit 433 .

6. Deciaration of intent to rezone "lakers together, town zoning ordtion of intent to rezone the point in r.yoming process at which town boar

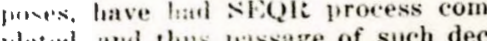
larition withent, or prior to, submissiou of draft environmental imma.t wate in direct contraWhline of SCQR requirements, and for this rianon alone, was invalid

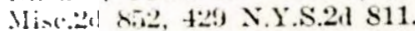
of Henrietta $v$. Dejarment of Enhatl W. as lead areney for SEQR pur 
grrv out its terms with mininum proceiural and art cle. They shall administrative delay, reporting and review requirements by providing, where feasible, for enmbined or consolidated proceedings, and shall expedite all procedings hereunder-in the interests of prompt review:

Added L.1975, c. $612, \S 1$.

Effective Date. Section effective Sept. 1, 1976, pursuant to L.1975. $6 T^{2}, 2$; amended L.1976, c. 228 , 4

\section{Generally}

In implementing this article. (1) apringes coust use the prenetlures in 6 Nivelik lart bit to the greatest exten: bossible, bat mas moxlify them

to accommodate the particular requirements of each agency; (2) any prorelural changes would be made hy the body rested with the authority to do so: and (3) the town board may not designate one agency as permanent lead agency. 1979, Op.Atty.Gen. (luf.) A pr. 26.

\section{\$ 8-0109. Preparation of environmental impact statement}

1. Aecucies shall use all practicable mesns to realize the policies anit anis sot torth in this articles, and shall act and choose altemative which, runsinteitl with socinl, economic and other essential conidrsativis, in the slitximum extent practicable, mininize or avoid adrers "arironmentit ertets, including eftects revealed in the environuental imurars statement proces

2 . All acrencies for afjlicant as hereinafter provided) shall frepare, "atus to be frepared by contract or otherwise an environmental im-

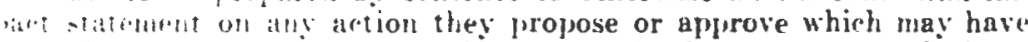
it sizhisant "iffer on the envionment. Such a statement shall inMule a detailon statement setting torth the following:

lat it desorifition of the proposed action and its environmental 6.:14u-

(b) the environniental impart of the proposed action including shortlerm atud longeterm etferets

(1.) any ahrere end ironmental effects which eannot be avoided should the prugkand bu jumplomented;

(d) altermatives to the proposed action:

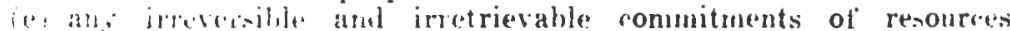
"hirh "ould be inwlivel in the poposed action should it be implemented: (i) mitration meanms proprosed to minimize the environmental mpaci

(2) the crowth-induring asperts of the proposed action, where up licable and sizhiticant:

(h) elfects of the polnened action on the use and consersation of energy sesureses. where alplieable and significant; and

(i) such oth+r intormation consistent with the purposes of this article as may be freseribed in guidelines issued by the commissioner pursuant to socion $\mathrm{x}-13113$ of this ehapter.

Surh in stafement hall also include ropies or a summary of the sub.

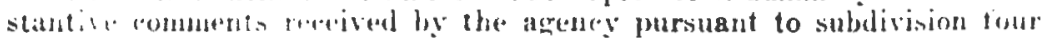

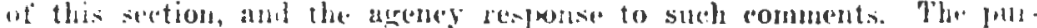

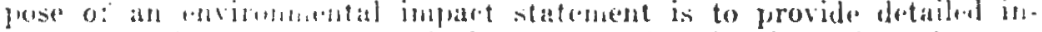

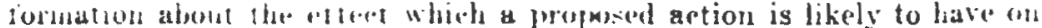
the environment to his ways in which any adverse effects of such an artion mirht be minimized, and to suggest alternatives to such an artion so as to forn the basis cor a decision whether or not to undertake or alyrove such wition. Wuch statement should be clearly witten in a concise manner adrable of being reatl and understool by the public - funh dea! with the specitic sirniticant enviromucstal impacts which
3. In arency may require an applicant to submit an environmental 3. An agency may require an applicant to subsonsibilities, includreport to assist the apene the applicant does not preing the initial deteris on pare the environnental impact statement), the preparationse an vironmental impact statement under this articte. - The agency may roquest such other information from an applicant necesary for the reiew of environmental inpacts. Notwithstanding any use of outside rew s'sourees ment of the

4. As early as possible in the formulation of a proposal for an action, the responsible agency shall make an initial determination whether an enthe responsible agency stan viromental impact statement need be py two or more agencics, such deaction is to be carried out or approved by two or more agencionation of the termination sha

With rawe to a o tions involving the issuance to an applicant of a Whith pertit or othere basis for writin of its intia dermination along with such detcrmination. Potice of the initial determination along we appropriate supporting findings on agency actions shall

If the agren statement is required, the agency If the ale or the applicant at ita option shall prepare the applicant does not exer(1)

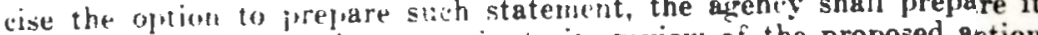
cunse it to be prevaretl, or terminate its review of the proposed action. Sueh statement shall deverib" the proposed action and reasonable althe artion and briefly discuss, on the basis of informaternntics to the submitted by tim the avalahe to relate sechion. The purpostion to the inception staternent is to relate envircminental ensiderations to the inception of the planning process, to intiorm the prublie and other pablic agencies us early as possible about proposel actims that may signifsantly affect the vurlity ot the miromunt, and to solict comments which will the qua decion making process in deternining the enasist the artion. The draft statement tisunn

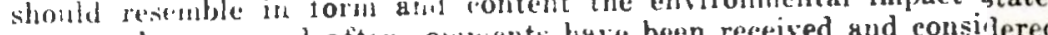
ment to be frepared after comming pursuatit to stablinis ion twro or Hetail of the dratt envirumuentul statement will necessarily reflect thes polimiang nature of the proposal and the early stage at which i is prepared.

The draft statement shall be filed with the departmont or other

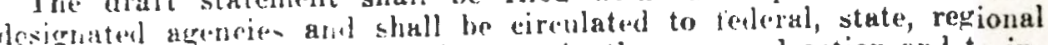
and lowe proposed action and to in-

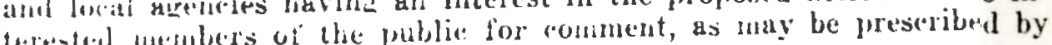

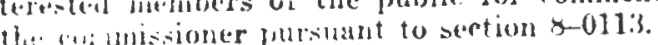

5. Siner thation of a draft ensironmental inpart statement the 5. shall delesmint whether or not to rondlact a publir hearing on

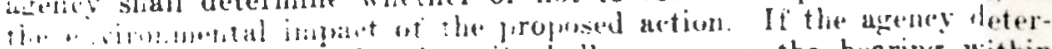
wiun to hold sueh a hearite, it shall commenee the hearine within ixy days of the filing and unless the pron is withdrawn from sixty days oi the fil ang and un

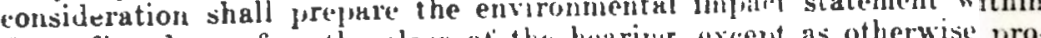
forty-five duys after the close of the haring, except as otherwise pro-

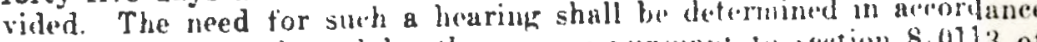

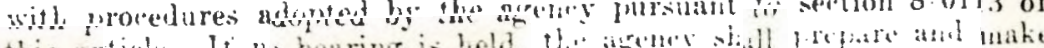


-.. urvaracu wine peroods established by this article, an agency shall vary the times so established herein for preparation, revien and public hearings to coordinate the environmental review process with other procedures relating to review and approval of an action. An application for permit or anthorization for an getion upon which a draft environmental impact statement is determined to be required shall not be complete until such draft statement has been filed and accepted by the ageney as satisfactory with respect to scope, content and adequec for purposes of paragraph four of this section. Commencing upon such scceptance, the environmental impart statement process shall run concurrently with other procedures relating to the review and approval of the action so long as reasonable time is prorided for preparation, review and public hearings with resnect to the draft environmental impact statement.

6. To the extent as may be prescribed by the commissioner pursuant to section 8-0113, the environmental inpact statement prepared pursuant to subdivision two of this section together with the comments of public and federal agencies and nembers of the public, shall be filed with the commissioner and made available to the publir prior to acting on the proposal which is the subject of the environmental impact statement.

7. An agency may charge a fee to an applicant in order to recover the costs incurred in preparing or causing to be prepared or reviewing a draft environmental impact statement or an environuental impact statement on the action which the applicant requests from the agency; provided, however, that an applicant may not be charged a separate fee for hoth the preparation and review of such statements. The technical services of the department may be made available on a fee basis reflecting the costs thereos, to a requesting agency, which fee or fees may appropriately be charged by the agency to the applicant under rules and regularions to be issued under section 8-0113.

8. When an agency decides to carry out or approve an action which has been the subject of an environmental impret statement, it shall make an explicit finding that the requirenents of this section have been met and that consistent with social, econonic and other essential considerations, to the maximum extent practicable, adverse environment:1 eiffects revealed in the environmental impact statement proecss will be minimired or avoided

Added L.1975, c. 612, §1; amended L.1977, c. 252, § 3 ,

1977 Amendment. Subd. 1. L. 19i7, c. 252. 3, June 10, 1877. practicable," precediag "minimize" and deleted "to the maximum extent practicable" preceding "shall act" and "of atate policy" tollowing "essential "of ztate policy"

Subd. 2. L.1977, c. 252, 3 , eff. June $10,197 \%$ inserted in the introductory text "(or applicant as hereinafter provided)" following "agencies", preceding "proponed action" in par. (g) and "enerky resourcen" in par, (b) the phrase ", where applicable and significant", the end phrase in par. (i) "of this chapter" and pro visions of last seutence relating in clarity of the witten statement, deal ing with the statedert of specific stgtement and in all cases pror to preparation of an environwental impact statement" following "action" substituted "ghall make an initial derination wether an environmenai impact stateñeñ ñeed be prepared for the action" for "mhall prepared the action prered a draft pare or cause to be prepared a ding in detail the proposed action and readetail the proposed action, sonalle alternatives to the action, information then arailable to the agency, the remaining items set fort is subdivision one herein" and adde urovision that such determination sliall be made as early as posatble after the designation of the lead agency when an action is to b carried out or approved by ipo or more agencies; jnserted second par. Prluting to initial determination of uctions involving issuance of a permit or other entitlement; insertel the three introductory sentences of the rhird uar. relating to the preparation of a draft eavironmental impact sratenent including description of th proposed action and reasonghle alter uatives to the action und brief discus vion of the remgining items to b submitted hy subd and reenarter submitt a the coschar secoud and third see iences of the firat par.

Subd. 5. I.1977, c, 252. 3. eff. Jula 10 . 1977, aldet provisions of Juze 10,1977 .

the seconil par. Subd. 7. Lat 1971, c. 25e. 3. ef June 10, 197f. autlorized a fee for the preparation. or jeview a nit probiled prohibited separate fees for buth the preparation

Subd. 8. L.1977. c. 252. 3, eff. June 10, 1077, deleted reference to requirements of sublivision one of this section and substituten "that consistent with social, econosulic and other essential considerations, to the maximum extent practicable, ad wrse eqviroumentail effects relealed in thif euvironmental impact statement pro. reos will be wininized or avoidm for "that all practicalle kintas will los tuken to minimize or as vill all. virste enironnental eftects."

Effectlvo Date. Section folfective siput. 1. 1976, pursuant to L.1979: 6. 61:2, 2; aneuded L.19i6, с. 22\%, 3.

Hibrary References

Ilralth and Foviroument C.J.S. Health uud Euvirounent $\$$ bi at
Generally 1

Aiseretion

Abuse of diseretion 3 statement 7

tement 10

acturs considered 8

Fladiags 9

orecast of fufure needs 13

Mosquito control, epraying 5

Necessity for statement

Notioe and hearling 12

Purpose of statement

Sufflelency of

Evidence is

Statem 2

1. Generally

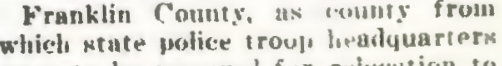
were la be removesh for sriakstion to Psmex County, did not have standing to bring suir for a julgmant derlarink that there had bep!n an illegal fuilur. to fully comply with assertodly andyli. cro pron Exerc con

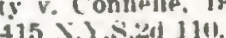

The bulaturing of progress aud yropTry righe with jureservation of lis oric entirunent is nor $\mathrm{H}$ inliais

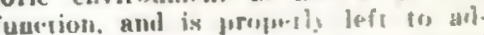

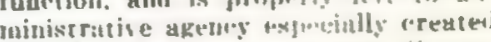
for that purpuse. (omptor syaste

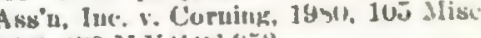

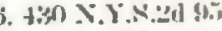

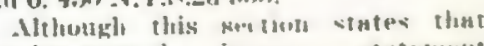
environthental imbart stutestent

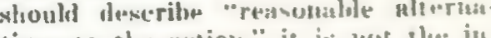
tives to the antion," it is $310 \mathrm{nt}$ han in

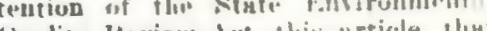

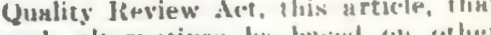


tlum euvirommental fuctors: it is m, the function of SF:QR to dirinte whis ukre must low male of privnle propert "von though it ma! restrint loshge th

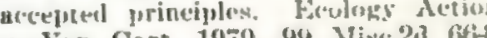


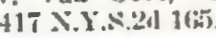

Reasonabla monsigh of titat per

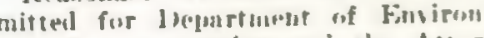
mental lonsersation and the Altur-

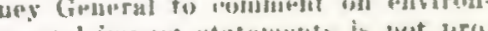

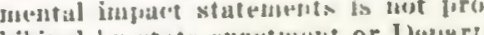
hibited by state "mactmedt or Deshart

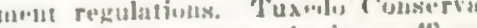

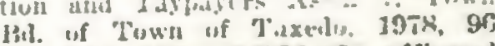
Hive:D] 1. tuk X.Y.S.21 bor, affirmed

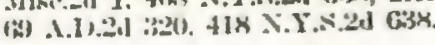

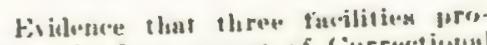

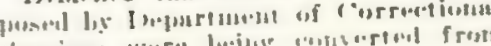

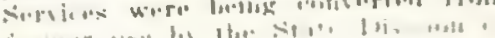


than they hert proviouste held that the third would have the sitme number of inm:ates, that nome of the faz"ilities nould require new dicy sewe or nater service, and that none of the facilities would have any impar on wetlands or air quality sustianed determination that prophiserl use of the facilitits would not have a significant effert on the emsirmment so that ne ellvironmental iminge state

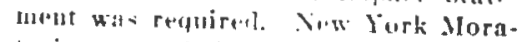
torium ont l'rimert cinner. 1. Etate th

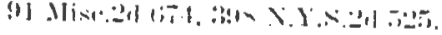

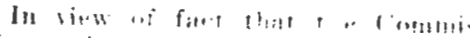

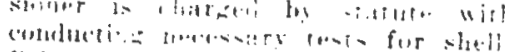

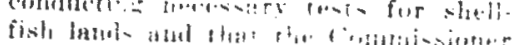

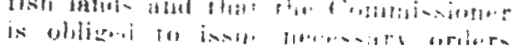

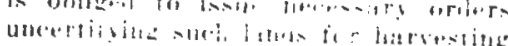

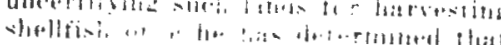

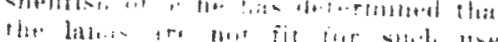

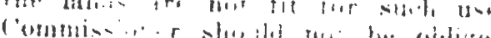

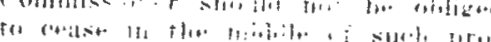

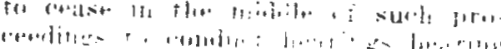

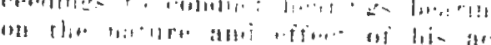

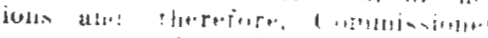

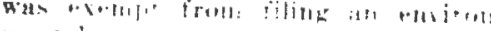

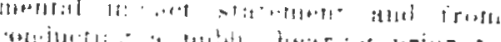

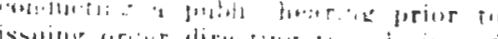

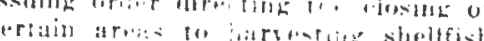
on mhlic i walth kroumis. Villani

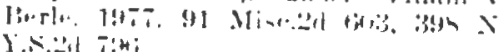

\section{Zoning}

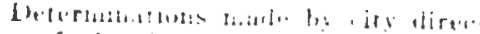

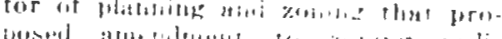

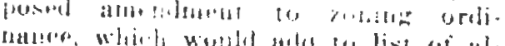

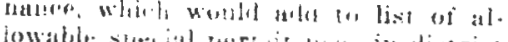

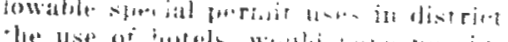

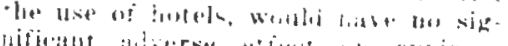

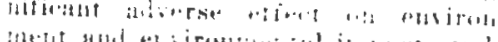

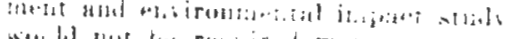

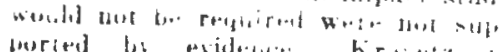
plonge, 1969,102 sis. X.s.s. 312.

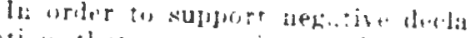

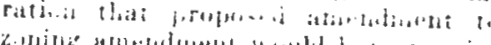

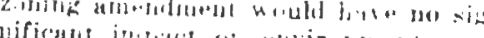

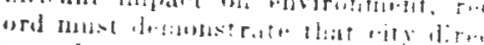

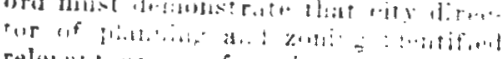

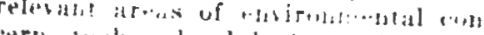

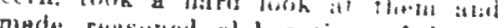

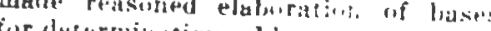

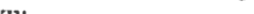

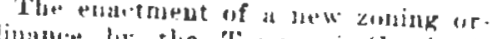

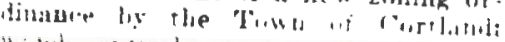

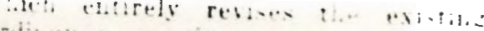

the pnartwent of a wholly new zoning ordinance and thus constitutes action requiring an environmental atatement under this article. 1978, Op.Attyent Iny $1 \mathrm{f}$.

\section{Abuse of dlecrotion}

Where town bont approved proposed $\$ 2(0,000,000)$ housing project on only the fourth business day after application. decision of town bar constituted gross ghuse of digeretion which deprived state agencies and pillice of their statutory right and - asomuble tima perion in wh to a

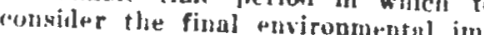
pact statement. Tuxedo ('ons in tion and Taxpacers Aws'n IBt. of Town of Tuxedo. 197s g6

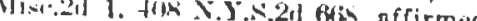

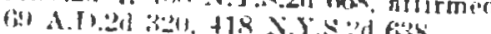

It was it lesst at abtase of discre tion. if not ille-gal, for tens board to bhansing beserd wirh resolution of extersicen to time Iopurte for aprusion ant cou-

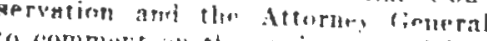
pect stazement for proposed housing dect statemint ior proposed housiug

\section{Necessity for statemen}

flosing of chamenzary scihool for

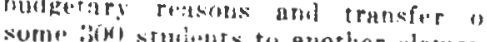

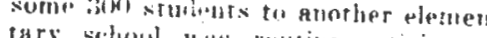
enluegtional institurion aretsir! of iuroles therefore in wastruction. and

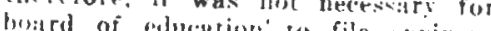

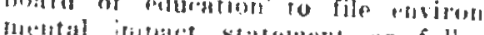

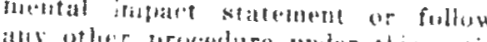

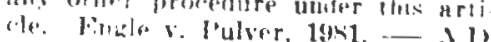

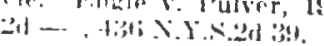

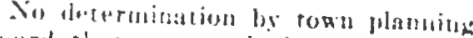

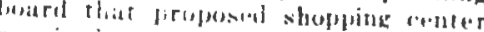

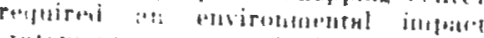

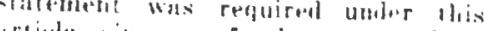

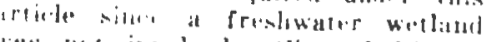

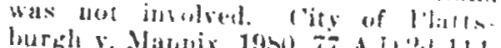

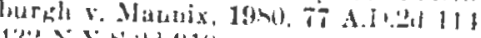
1:32 N.Y.S.2. 910

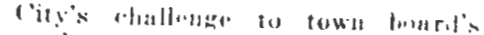

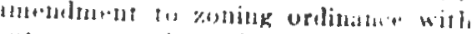

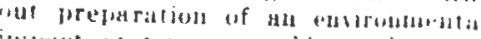

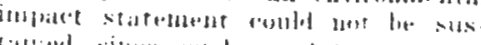

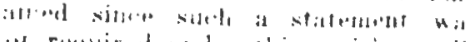

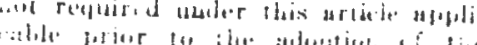

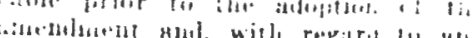

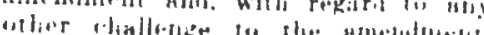



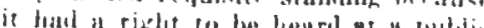

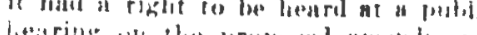

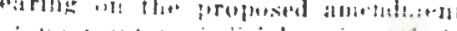

Githin Euvironmental Conservation ax as a project for which an environmental impact statement quirerl, filing of statemont whs reyuired where such project had signif. icant impact on exvironment. - H. 0 . I. E. S. v. New Tork State Urbau hevelopment Corn. 1079. 69 A.D.2 22, 418 N.Y.S.2d 827.

To support Inivision for Youth's de. ernination this conversion of three-building section of state mentrl f.uspital into detention facility for ju. reuiles convicted of sitrious crimes would not have a siznificant impact a) the environment and that there. fore no euvironnental inumet stutement was resuired the rucord had to how tiat the loivision idantifiel the celersut a ress of the environausent

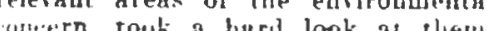

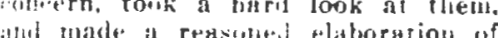
the basis for its dererminurion Itur.

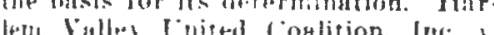

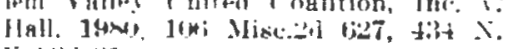
Y.t.:

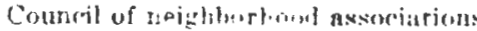

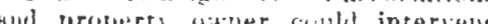

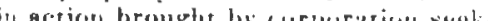
ing to athul determidation of rise o.the

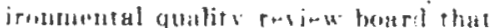
proposed deninlition of certuin uremises harl no signifina:- impale ugn:

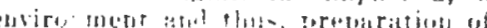

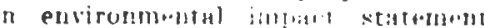
*as not resfuirel por-uant to this

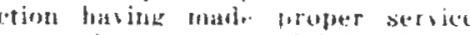
on opposing purties atwi being iurer.

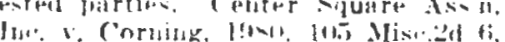

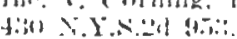

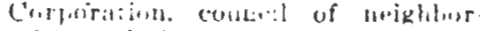

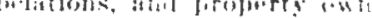
er had suffiriont ser.t.ding to matil-

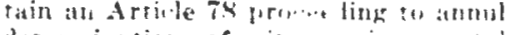
Aptromiuntios of city envirentments quality revim lesare that propasond




matar and plas, prejat ation of an en-

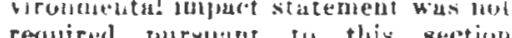

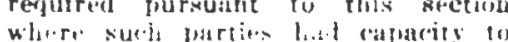

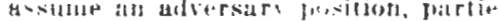

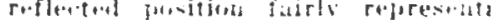

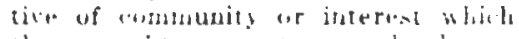

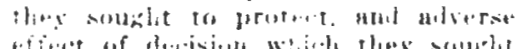

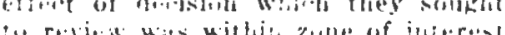

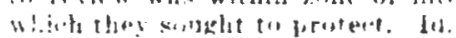

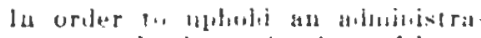

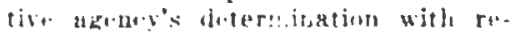

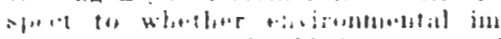

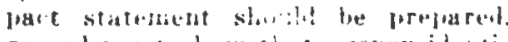

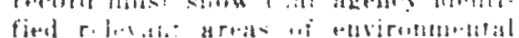

Fividence before the Department of tained fiuding that its rules and regulations implementing Real Property Tax IAW 48h-a providing for par tio tax exemption for forest land would not huve a signifiesnt impact on the ebrironment so as to requir the preparation of an environmental impact statement. Honeoye Central Srhool Dist., Town of Livonia $\mathbf{v}$. Herle, 1979, 99 Misc.2d 20, $415 \mathrm{~N}$. Yis:2d 5 if5.

\section{Mosquito control, spraying}

Village's mosquito comfort contro program which involved the aerial spraving of pesticides was subject to the requiremeits of section 8-0101 et ve?. and therefore. village would br enjo.jned from condueting furthe afrint spruging in connection wit mostututo control program until it ronilliesl with such statutes by performing st environmental impact studi and filing a statement. Harino r. I'latt. 1980, 104 Misc.2d 386, 428



\section{Purpose of statemen}

riniment statement, as rincer to fect 1. iw bav ou the enviromment, to list walk in which ans adverse effects of surth artion inight be minimized, and II. suggesic vitrornatives to such action su as to torm basis for decisio whether to undertake or approve suc wisun. Toun of flenrietta $x$. De

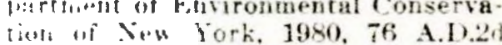
thet

Fuvirominat impact statement rectuired under this article for any ac tion whirh luny have significant effect whe the mirmment is meant to be murm thitin simple disclosure state min.t. ratler, it is to be reviewed as mabrommin alarm bell whos "urpun is to ulert responsible publi

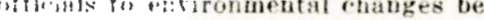
fort they hise reached ecologicat porinis of mo refurts. Fo.

Siluet Statk Enbironmental Quality l.abien det rengures approwing agen$\because$ ro ate htc...nntively upon adverse

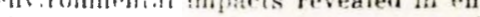
A rombart statement, such

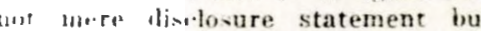
ralier us ail in agnency's decisionmak che process on evalo and balance

7. Applicablitity of statement

Ap pllcabinty of statement sutument 
Conservation of New York, 11\%). T( $4.215,430$ N.Y.S.21 440

8. Facters considered

This article reyuires approving agency to consider fully environment consequences revealed in environmencol impere cunsequences lnto account when reaching decision an to whether to etin

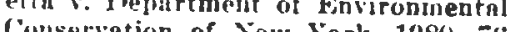
tine it A.I.2A 21? 430 X.Y.i.2. 440 .

\section{Findings}

Akency which aldproves all Hetion must make witten finding that it hes.

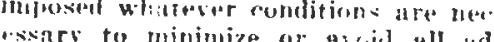

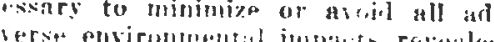

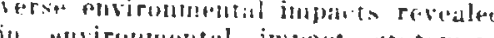
ill "msirommonth implate statement of Ilenriets "if Tenriets s. Fepmrtment of Fin

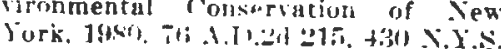
(1)

10. Evidentiary effect of statement

While embironmental impare sute ment filed furstumi to this article does not require fublic ay.nr. to act

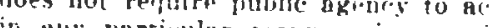
tutes evidenes which niust be rent

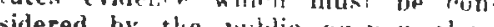

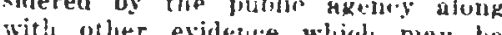
with other exidesue whicd nuay be presenterl. Tonn of Henrietta lepartment of Finvironmental ron servation of Nen lork, 1986, i6 A.I . 1] 215,430 X.Y.S.2d 440.

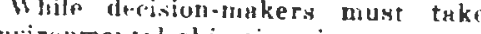
encironmental olyeretives into arcount. shtisfactory answers to thas. oljece. fives may be provifarl hy reference to

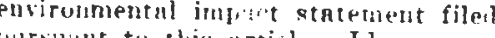
mursiant to this articts. Id.

11. Sufficlency of statement

'luwh boarl, whirl, hal rezoned subject property frum commercial shopping renter atistrict to plabned

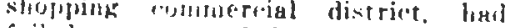
folled to meet am druft euviroumelital milact statement as satisfactors wit! respert to sivon, contents and adkefuary, as required by rekulations.

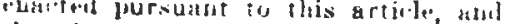
thus board's alenitrittion of inte: it the

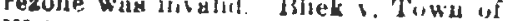

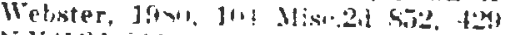
X.x.s.d sil.

\section{Notice and hearing}

1)ivision for liouth was ordered io condure foublio hearing before deterinithing whether consersiot of thror

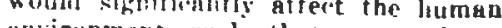
minirumen sirli that an environnichtal impurt statement nould he required, not withst anding the lack of stafutory or itrlmitustritive provision for surb. mubli. hearing. Hsrled Salley, rniled Co: ition, lnc. v. Hall 1980, 106 Misc.2d 62T, 434 N.Y.S.2d

Fact that town board, which had rezoced suhject property from com mercial shopping center district to plummel shopping commercial district.

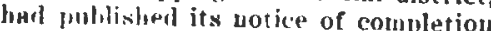
of iraft movironmeral impact stute mont slm notice of public heariug in werekly ne wespaper distributed in tow aren bof not dist ributed regionally did mot mesn that bon doad not plient with repulation remuiring pub-

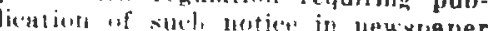
of generial circulution, a-liere areaper potential impace in environmentul

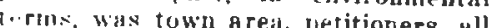
uf uhom lived or owned propert in


ly werkly newspatuer, and they not argue that they did not reate

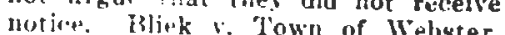
1951, 104 Mise.2. $\times 52,+29$ X.Y.S.2d Nil.

Town beurd which he rexnet Fowr lestril. which had rezoned sulligw propuerts from commercial shoming center distriet to planned rumeous fuiled to file dist rirt, had er

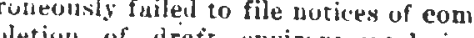
phetion of draft enviromental itu Herith state and federa reguired by in tinely manner as with resuli haphirahle regulation. with result that vistlication by De

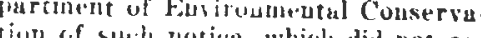
hor of sur ho botwe. which did not or rur until after public hearing on iraf what restive, and thus, on remant. town was directed to file requiren notile in timely fashion with state and federal clearinkliouses. Id

\section{ast of future needs}

Lecision-makers ure not priduded frum formastiug tuture needs; lath. "romete are ptacouraged to make rea somable formants in prejarafion of

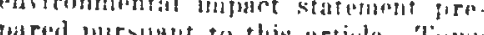

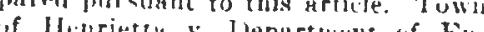
cironmental Gonental



\section{Sufficiency of evidence}

("ily envirunmental quality resien bourd's issuance of permit for demo. arlit rary and cain bremises was dowe in iu viuliciun of manlates of this ond iary elusence presented to bos rd wus directly costrary to their findings, chy urba renewal asency found the prenise was most simnifleast ex-

1. State and federal reports coordinated. Where an agency as herein defined directly or indirectly participates in the preparation of or prepares a statement or submits material relating to a statement prepared parsuant to the requirements of the National Environmental Policy Act of $1969,{ }^{1}$ whether by itself or by another person or firm, compliance with this a wele shall be coordinated with and made in conjunction with federal requirements in a single environmental reporting procedure.

2. Federal report. Where the agency does not participate, as above defined, in the preparation of the federal environmental impact statement or in preparation or submission of materials relating thereto, no further report under this article is required and the federal environmental impact statement, duly prepared, shall suffice for the purpose of this article.

3. State and local coordination. Necessary compliance by state or local ageneies with the requirements of this article shall be coordinated in accordance with section 8-0107 and with other requirements of law in the interests of expedited proceedings and prompt review.

4. Effective date of coordinated reporting. The requirements of this section with regard to coordinated prepuration of tederal and state impact materials and reforting shall not apry to statements prenared and filed prior to the effective date of thi- artini

5. Exclusions. The requirements of sublivision two of section b-0109 of this article shall not apply to:

(a) Actions andertaken or apfroved prior to the effective date of this article, except:

(i) In the case of an antion where it is still practicuble either to modify the action in such a wa as to mitirate potentially adverse enviroumental effects or to choose a lewsible and less onironmentally damaging alternative, in which rase the cummissioner may, at the request of any person or on his own motion, in a particular fase, or generally in one or more classes of cases specifited in rules and regulations, require the preparation of an environmental impact statenient pursuant to this article; or

(ii) In the cuse of an action where the responsible agency proposes a modification of the action and the modification may result in a significant adverse ef fect on the enviruntent, in which ase an environmental impact statement shall be prepared with respect to such modification.

(b) Actions subject to the provisions reyuiring a certificate of environmental compatibility and public no. it it articles seven and eitht of the public service la $\mathrm{k}$; or

(c) Actions subject to the class A or class B regional project jurisdiction of the Adirondark park agency or a local government purstiant to section eight hundred seren, elfit hududed tigit or eght hutuld vine of the executive law:

6. Lead Agency. When an action is to be carried out $r$ approved by two or more agencies, the determinution of whether the action may have a significant effect on the environment shall be made by the lead agency having principal responsibility for carrying out or approving such action and such agency shall prepare, or cause to be prepared by 
were is a yluestion as to when is the lead agency, any agency may subnit the question to the conimissiorer and the commissioner ohall designate the lead agency, giving due consideration to the capacity of such agency to fulfill udequately the requirements of this article

Adted L.1975, e. 612, §-1;-amended L*1977,-c. -252, \& 4; L*1981,-c. 119 $\$ 1$.

142 U.S.C.A. $\$ 321$ et seq.

1981 Amendment. Subd. 5, par. (c). L.1981, c. 119, \& 1, eff. May 18, 1981, inserted "class A or class B regional prujert" and "eight liundred seven, eirht hundrell pight or".

1977 Amendment. Subs, 2. L. 1977. . 2.2. 4, off. Ture 10, 1977 , delerod from the heruling "t" be sup-

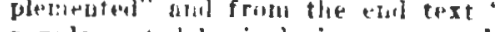
supplement...t by idolusion as may be applicable of thost items of report

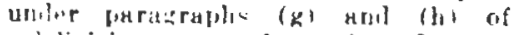

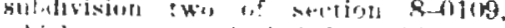

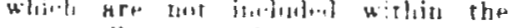

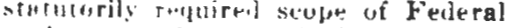

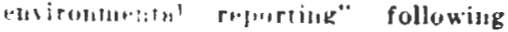
"urbusen of tlis article.

Effective Date. Siection effectiv. selp. 1. 19ti, iursilant ro L.1975. c. 612,8 2 2 : am: t.

\section{Index to Noter}

Alr qualty monitoring 2 Functions of lead agency

\section{8-0113. Rules and regulations}

1. Atter consultation with the other agencies subject to the provisions of this urticle, inuluding stute acrencies and representraties of locu! gownhwnts and after conducting public hearings and review of any other cumuments submitted, the commissioner shall adopt rules and reailian: implementinu the provisions of this article within one hundreit und wonty days ajer the ef fertive date of this section.

2. The ruhes and regulations adopted by the commissioner specifically shall include:

(u) Detinition of terms used in this artiele;

(b) Crituria for deteruining whether or not a proposed artion nay hase a significant aftere on the environment, taking into account

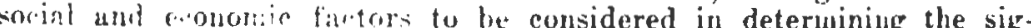

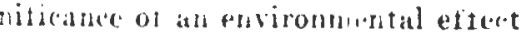

(c) Identitication on the hasis of such criteria of :

(i) Actons of clasers of Hetions that are likely to require prepara tion of envirommental impact statements;

(ii) Actions or clusses of actions which have been determined not to have ignificant effect on the environment and which do not requir envirmuental impact statements under this article. In adopting the rules and regulations, the commissioner shall make a finding that pach *lion or class of actions identified does not have a signifieant efluet on the enviromment: sessing such extects, of artions dotemined to be likely to require preparation of environmental inupact statements;

(e) Categorization of artions which are or may be primarily of statewirle, regional, or locnl concern, with provisions for technical assistance including the preparation or review of environmentai impact statements, if requested, in connection with environmental impact review $\overline{b y}$ local agencies.

(f) Provision for the filing and circulation of draft environmental inpact statements pursuant to subdivision four of sertion 8-0109, and environmental inpact statements pursuant to sublivision six of section 8-0109;

(g) Srope, content, filing and arailability of findings required to be made pursuant to subdivision eight of section 8-0109

(h) Form and content of and level of detail required for an environmental impact statement; ani

(i) Proceduren for obtaining comments on draft encironmental impact statements. holding hearings, providing wublic notice of ageney decisions with resp...t to prejaration of a drat environuental statement; and for surh other matters as mal be needed to asme effective participution by the public and efficient and expeditions arministration of the article.

(j) Procedure for providing applicants with estinates, when requested, of the costs exfected to be charged them pursuant to subdivision seven of section z-0109 of thi- article.

(k) Alneals procedurt for the settlement of disputed costs charged by state acerace to Rupliennts pursuant to subdivision seven of section g-0109 of this article. Surch appest promelure shall not interfere or eause delas in the detemination of envirumental significance or prohibit an action trom bein undertaken.

(l) A model assessment form to be used during the initial review to assist an ageney in its respronsibilities under this articin.

3. Within the time periods sperifiel in section $5-(1117$ of this article the areneies subjert to this urticle shall, atter public hearing, adopt and publi-l such additional proredures us may be necessary for the implementation by them of this article consistent with the rules and regnlations adopted by the commissiones.

(a) Existing anency envirommental provedures waty be ineoryorated in und inten ruled with the procedures gulopted under this article, and

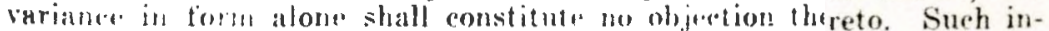
dividual areney prodedures shall be no less protertive of environmental

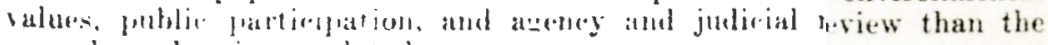
proecedures herein mamdated.

(b) Such atrocy promelures slabll provide for interagency working relationships ${ }_{\text {in }}$ cases where artions typically involve more than one

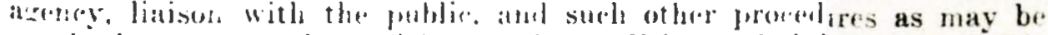

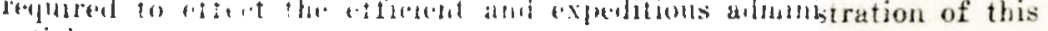
articla

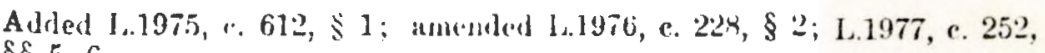
$\S \S 5,6$.

1977 Amendment. Nuld. $\because$ lour (1) 1.1967. . . I11. $197 \%$ deleted "witl. "xumple.

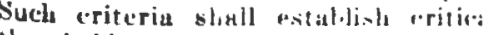
thresholds for the lawalth and safiet of the preople of the siate, and pro. tection of the .. wiroment." precent ing "taking : • : a want"
Subel. 2 bars (J) to (l). 1..1:77,

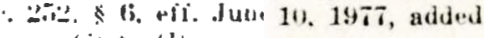
pal rs. (j) to (l).

1976 Amendment. L.1976, c. 228. \& ¿ eff. Mity … 1976, substituted

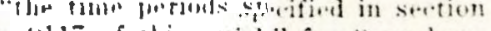

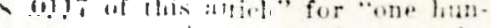




Enectivo Dafo. Section effective Sept. 1, 1975, pursuant to L.1975, c. 612, 2; amended L.1976, c. 228,

Roujow and-Amendment of Ruies and Regulatlone Conoeralog Environ. mental Impact stalement 1078 . 460 , f 4 , eff June 30,1978 provided: - Por the porpones only of provided: proceduresurponen only of mimplifying procedures and clarifyng the identification of actions and classes of acration of are likely to requile prepaatatement as such matters are includ. atement as such inatters are includ. ed in rules and regulations adopted purruant to subdivision one of section $8-0113$ of the enviroumental conser vation law [subd. 1 of this section] the commissioner shall, wholly con sistent with the provisions of article eight of the eavironmental conservi tion law, review such mles and regu lations and adopt amenriments to such rules and regulations not later than the first day of septemher. nineteen hundred seventy-eight."

\section{Library References}

Health and Fnvironment $\Leftarrow 20$.

C.J.S. Health and Environment

$$
\text { et seq. }
$$

\section{\$ 8-0115. Severability}

The provisions of this article shall be severable, and if any clanse, sentence, paragraph, subdivision or part of this article shall be adjudged by any court of competent jurisdiction to be invalid, such judgment shall not affect, impair or invalidate the remainder thereof, but shall be confined in its operation to the alause, subdivision or part thereof directly involved in the controversy in which such judgment shall have been rendered.

Added L.1975, c. $612, \$ 1$.

Effoctive Date. Section effective Sept, 1, 19i6. pursuant to L.1975, c. 612,2 ; anended L.19i6, c. 228, 4.

Library References

Sitntutes $960+(2)$

('.t.s. Statutes 806 et seq.

\section{8-0117. Phased implementation}

1. With respect to the actions directly undertaken by any state agen. cy, the requirement of an environmental impact statement pursuant to subdivision two of section 8-0109 of this article shall take effect on the first day of September, nineteen hundred seventy-six.

2. With respect to actions or classes of actions identified by the department as likely to require preparation of enviroumental impact statenents pursuant to subparagraph (i) of paragraph (c) of subdivision two of section 8-0113 of this article directly undertaken by any local agenes, whether or not such actions are supported in whole or in part through contracts, grants, subsidies, loans, or other forms of funding assistance from one or more state areucy; and all other actions or classes of actions identified by the departmient as likely to require preparation of environmental impact statements pursuant to subpara. Frapla (i) of paragraph (c) of sublivision two of section s-0113 of this siques, loans, or other tiorms of tur ling assistance from one or more state agency, the requirement of an environmental impact statement pursuant to subdivision two of section 8-0109 of this article shall take effect on the first day of June, nineteen hundred seventy-seren.

3. With respect to actions or classes of actions identified by the department as likely to require preparation of entrironmentat impact statements pursuant to subparagraph (i) of paragraph (c) of subdivision two of section 8-0113 of this article supported in whole or in part through contracts, grants, subsidies, loans, or other forms of funding through contracts, grants, subsidies, loans, or other forms of funding or classes of actions identified by the department as likely to require preparation of environmental impact atatements pursuant to subparagraph (i) of paragraph (c) of subdivision two of section 8-011.3 of this article involving the issuance to a person of a lease, permit, certificate or other entitlement for use or peruission to act by one or more state or local agency, the requirement of an environmental impact statement pursuant to subdivision two of section 8-0109 of this article shall take effect on the first day of September, ninetcen hundrcil seventy-seven.

4. With respect to all other actions not inchuded in subdivision two or three of this section which are subject to this article, the requirement of an environmental impact statement pursurnt to sublivision two of section 8-0109 of this article shall take effert on the first day of November, nineteen hundred seventy-eight.

5. Agencies subject to this article shall wlopt and publish the additional necessary procedures described in subdivision three of section $8-0113$ of this article, as follows:

(a) With respect to actions included within subdivision one of this section, no later than August 1, 1976.

(b) With respect to actions included within subdivision two of this seetion, no later than April 1, 1977.

(e) With respect to actions ineluded within subdivision three of this section, no later than July $1,1977$.

(d) With respect to actions included within subdivision four of this section, no later than November 1, 1978.

Any ageney which has not adopted and unhlisherl the additional necessary procedures described in subdivisions fwo thit three of section 8-0113 of this article according to the dates set forth in this section shall utilize those procedures found in Part 617 of title six (environmental conservation) of the official compilation of the codes, rules and regulations of the state of New York for purposes of implenenting this article until such time as such agency las adopted and published its ow'n procedures.

Added L.1976, c. 228, § 3; amended L.197T, c. 252, §§ 7, 8; L.1978, c. $460, \S \S 1,2$

1978 Amendment. Subd. 4. I. $197 \%$, c. 460 . 1 , eff. June 30,1978 substituted "Nosember" far "Septem-

Subd. 5, par. (d). L.1978, c. 4 (6), 2 eff. June 30 , 1978, substifuted "Vovember" for "July".

1977 A mendment. Subds. 2. 3. I 1977 , c. 252, \& $T$, eff. Juze 10 , 197 inserted in two instances in sulds. and 3 "or classes of actions identifien by the department as likely to require j,reparation of ellviroumental impact statements pursuant to subparagraph (i) of paragrapls (c) of subdivisiou two of sectiou $S$ (1)113 of this arricle" folleuling "Mctions"
Suld. 4. I.1977, c. $252, \& 8$, eff. June 10. 1977, and $\bullet$-d sulk. 4. Forn-

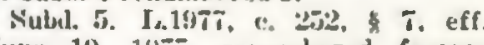
Jum 10, 197\%, selsunbered former sutal. 4 is 5 and nilled par. (d) anel provisjons of last bar. Jeertaining to mplementution of this artiole

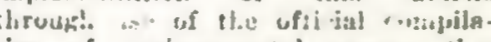

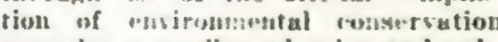

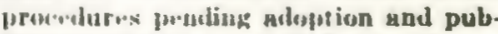
contion of the prescribst uresedures. Effective Date. Sintiun effortive

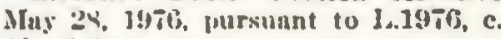
20.515.

List of Approved Projects Not Subject to Artiste 8, Availabillty for er sulst. 4 renumbered 
ed by L.1978, c. $460, \& 3$, eff. Jun provided

" 8. For the purpose of clarify lng the jdentification of actiong di rectly undertaken by a local agene included within aubdivision two of section 8-0117 of the environments conservation [this section] law which have been approved by uch agency prior to the first day of June, nineteen hundred seventy-geven and therefore, not mubject to the proviaions of article eight of such la [this article], not later than September first, nineteen hundred seventyseven, each local agency shall submi to it chief fisral officer a list of projects which such agency deems to have been approved. Within thirt days of such submission, the chief fiscal officer sliall review such lists to certify that substantial time, work or money have been expended on such projects. The local ageney shal maintain a copy of such certified list of projects which shall be deemed approved and therefore not subject to the provisions of article eight of the environmental conservation Such list shall be available for public inspection in the municipal office of such agency.

"B 10. For the purpose of clarifying actions supported in whole or in part by form of funding anger in from one or of fung assistance agencies included within subdivisions two and three of wion the andiros which fore have been apjored and therearticle subject to the provisions of article eight of such law, each such officer a list of project offer a list or projects which such ageacy deems approved (1) in the cy or state agency funded projects,

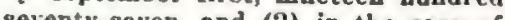
geventy-seveu, and (2) in the case of lockl agency funded project, by Novemer first, aneteen hundred seventy-seven. Within thirty days of suc ubbission, the chiel fiscal of fice sull review auch lists to certify tha applications submitted to such agenty have been approved or are in an approvable form. Each agency shal maintain a copy of sucl certified list of projects which shall be deemed approved and therefore not subject to the requirement of mu environments impact atatement. Such lists shall be available for public inspection in the main office of such agencies.

"I 11. The provisions of article eight of the euvironmental couservgtiun law shall not ayyly" to actions in. zation for use or perming or authonfor use or permission to act or which all final approvals shall dove first day of September, nineteen hundred seventy-seven-from local and state gencies having juriediction over such actions. An wed in this rection, the term 'final approval' shall mean:

"(a) in the case of the subdivision of land, an action in the nature of a conditional approval of a preliminary or final plat on that term ln defined in section two bundred seventy-six of the town law, and an action in the nature of an approval of prelimiary plat with or without modification as defined in section 7-728 of the village law and section thirty-two of the general cities law:

"(b) in the cage of a wite plan special permit, special use, conditional use, exception, variance or similar apecial authorization, an action in the nature of an approval with or rithout conditions or modification by the appropriate local body islative body, boand of appeals or planuing board:

(c) in the case of all other sucl actions requiring a permit or authorization from atate or local agency. the granting of each such permit or

" 12. For the purpose of clarifying the identification of actions directly undertaken by a local ageucy cluded within subdivision four of conservationmenta couservation law which have been ay first day of dred lay of . Tovenber, nineteen hun subject to theight and, therefore not eight of the provisions of articte eiglt of such law, not later tiran $N_{0}$ ver-eiclit, firstis tive to mit to its chief fiscal officer $n$ list of projects which such ageucy deens to have been approved. Within thirty days of such submission, the chief fiscal officer shall review such list to cerrify that substantial time, work or money lave been expented ou such projects. The local agency shall muiatain a copy of suchi certified lixt of projects which slabli be dermed approved aud therefore not subjert to the provisious of article eiglit of the conservation law. Such list shall be available for public inspection in the nunicipal office of surlit ageney.

-13. For the purpose of clarify ing actions supported in whole or in part by a form of funling assistanee ronmental conservation law which have been approved prior to the first day of November, nineteen hundred seventy-eight and therefore not sub. ject to the provisions of article eight of buch law, each such agency shall submit to its chief fiscal officer a list of projects which such agency deems approved (1) in the case of state agency funded projects, by November first, mineteen hundred seventy-eight, and (2) in the case of local agency funded project, by [September] No. vember first nineteen hundred seventy-eight. Within thirty days of such submission, the chief fiscal officer shall review such lists to certify that applications submitter to such agenc provable form. Each agency slal provable form. Each agency sliail maintain a ropy of such certifted list of projects which shall be deemed approved and therefore not subject to impact statement. Such lists shent irapact statement. Such lists shall be main office of sucls agencies.

"8 14. The provisions of articl eight of the earironmental colserv cion law shall not apply to actions includer within subdivision four of section 8-011T of such law requiring the issuance of a permit or authorization for use or permission to act for which all fingl approvals shall have been obtained prior to the first dy of November, nineteen liundred seventy-eight from local and state agen. cies having jurisdiction over such actions. As userl in this section, the term "final approval" shall mean:

"(a) in the case of the subdivision of land, an action in the nature of an approval of a preliminary plat as that term is defined in section tu hundred seventy-six of the town law and an action in the nature of an ap proval of a preliminary plat with o writhout modification as defined in section 7-728 of the village law and an action in the nature of an approv al of a plat with or without modifications as referred to in section thirty-two of the general cities law

(b) in the case of site plan, special permit, special use, conolitiona use, exception, varialuce or simila suerial authurization, an action in the nature of an approval with or with out conditions or modificatious by the islative body, board of appeals or planning board;

"(c) in the case of all other such ctions requiring permit or authort zation from a tate or local sgency the rranting of each ouch permit or authorisation."

\section{Llbrary Reforences}

Health and Environment $\rightleftharpoons 25.10$ C.J.S. Bealth and Eavironment 164 et seq.

\section{Index to Note}

Applicabillty

Environmental Impact statement 2 Measures to mitigate adverso of lects 3

\section{Applicability}

This article was inapplicable to subdivision approvals granted by toxy planning board on ground that prelimiosery and final plat approvals were given prior to effective date of od 726, 412 N.Y.S.2d 659 .

2. Environmental impact statement

Where condemnation action was un dertaken or proved prior to effective date of this article, no environments impact statement was required to be filed and exception, i. e., requirement that an impact statement be filed nontheless, could only come into being upon initiative of the Commis. sioner who hud not so acted in parcicular cese New Yor State Urbap Development Corp. V. Vanderlex Merchandise Co., Ine., 1978 ,

\section{Measures to mitigato adverse of}$$
\text { fects }
$$

This article authorizes approving agency to implement measures designed to mitigate adverse environmental impacts identified, so long as these measuren are reasodable in scope and are reasonably related to adverse impurts identified in environmental impact statemeut. Town of Henrietta v. Department of Fisvironmental Con2.l 215,430 N.Y.S.2d 440 
APPENDIX 3. Webster Zoning Ordinance. 
A. All uses permitted in an R-3 District are permitted uses in a $C-S$ District subject to the dimensional regulations of the R-3 District.

*B. The Town Bnard inay establish a PCS Planned Shopping Center District in a C-S District in accordance with procedures set forth in ArLicles IV and $V$ hereof.

\section{ART ICLE IV}

Establishment of Planned Unit Development Districts

:59-2]. Districts cstahlished.

The Town Brard may, in areas designated on the Zoning Map of the Town of Wolufor, cstablich plamod unit development districts as follows:

A. PRA Planned Mixed Residential District: within an R-A District.

B. PRB Planned Nultiple Family Residential District within an R-B.District

C. PRC Planned lultiple Family Residential District withiu an R-C.District

D. PRR Planned Residential Recreation District within a P-R District.

*E. PCN Planned Mixed Residential Neighborhood Commercial District within an R-3 District.

WF. PCS Planned Shopping Center Commercial District within a C-S District.

\section{$59-22$ Intent}

It is the intention of the planned unit development (liereafter called "PUD") section to provide perfortance criteria and permit regulatory flexibility which can result in stnall-to-jarge-scale residential, comtercial and mired developments within designated districts incorporating a variety of residential housing types and related nonresidential uses, and containing both individual building sites and conmon property which are plamed and developed as a unit. Such a planned unit development shall be designed and organized to operate as a separate entity without dependence upon the participation of other building, sites or other conmon property. This section is intended to encourage innovations in resirential and comberal developinent so that the growing demands for houring at all economic levels nay be met by consitruction of a greater variety in type, design and layout of dwellings and by the conservation and more cfficient use of land in such developments. Comercial, retail and service functions are encouraged on a planed basis to serve expanding residential areas to be conveniently located in such a manner as to bJend and coordinate residential and combercial usps in the best interests of the entire cominumity. 
In order to carry out the intention of this section, a PuD shall be designed to achieve the following objectives:

A. A maximun choice in the types of environment, occupancy tenure (e.g., cooperatives, individual, condominium, leasing) types of housing, lot sizes and community facilities available to town residents at all economic levels.

B. More usable open space and recreation areas and more convenience in location of commercial and services areas.

C. A development pattern which preserves trees, outstanding natural topography and geographic features and prevents soil erosion.

D. A creative use of land and related physical development which allors an orderly transition of land from rural areas.

E. An efficient use of land resulting in smaller networks of utilities and streets and thereby lower housing costs.

F. A development pattern in harmony with the objectives of this ordinance.

G. A more desirable environment than would be possible through the strict application of other Articles of this ordinance.

59-24 Approval required.

Whenever any planned unit development is propesed, beforc any permits for the erection of permanent buildings in such planned unit development shall be granted, and before any subdivision plat of any part thereof way be filed in the office of the Monroe County Clerk, the developer or his authorized agent shall apply for and secure approval of such planned unit development in accordanro with the procedures set forth in this ordinance.

59-25 Application for sketch plan approval.

A. The applicant shall first submit a sketch plan of his proposal to the Plaming Board. The sketch plan shall be approximatcly to scale, and it shall clearly show the following information:

(1) The location of the various uses and their areas in acres.

(2) The general outlines of the interior roadway system and all existing rights-of-way and easements, whether public or private.

(3) Delineation of the various residential areas indicating the number of residential units in each of the five (5) categories; single-fanily detached, single-family seri-detached, two-fanily town house and multiple-family; plus a calculation of the residential density in dwelling units per acre for each such area and overall district density.

(4) The interior open-space system.

(5) The interior drainage system showing drainage flows to streams and any existing watercourses.

(6) Principal ties to the community at large with respect to transportation, water supply and sewage disposal.

(7) Estimates of the additional school population and possible allocation to existing and proposed schools.

(8) A location map showing uses and ownership of abutting lands. 
B. In addition, the following documentation shall accompany the sketch plan:

(1) Evidence of how the developer': particular mix of land uses meets existing conmunity demands.

(2) Statement as to how common open space is to be owul adid mintained.

(3) If the development is to be staged, a clear indication of how the staging is to procend. Whether or not the development is to be staged, the sketch plan shall shou the cntere proposed project.

(4) Evidence in the applicant's own behalf to demonstrate his competence to carry out the plan and $h$ is awareness of the scope of such a project, both physical and financial.

(5) A calculation of the ratios of the types of residenial dwel1ing units and the percent of land and building area to be devoted to each type of residential use and commercial use.'

(6) Certificate by the Town Assessor that the proposed multiplefamily dwelling units, when constructed, taken together with existing multiple-family dwelling units, and units for which building permits have been issued, will not exceed approxinately twenty percent (20\%) of the single-family detached dwellings in the town, excluding the Village of Webster.

(7) A written statement certified by an authorized representative of the applicant in compliance with Section 59-100.

C. The Plaming Board shall review the sketch plan and its related documents; and shall render either a favorable or unfavorable report to the applicant. and the Town Board.

(1) A favorable report shall be based on the following findings which shall be included as part of the report:

(a) The proposal meets the objectives of planned unit development as expressed in section 59-23.

(b) The proposal meets all the general requirements of the appropriate PUD section of this orlinance. 4

(c) The proposal is conceptually sound in that it meets a community need and it conforms to accepted design principles in the proposed functional roadway system, landuse configurations, open-space systea, dráinage system, and scale of the elements both absolutely and to one another.

(1.) There are adequate services and utilitics available or proposed to be made available, in the coustruction of the development.

(2) An unfavorabie report shall stale clearly the roasons therefor, and, if appropriate, point out to the applicant what miglit be done in cider to receive a favorable report.

(3) If no report has becu rendered within sixty (60) days of submission to the Platuing Board, the applicant mav proceed as if a favoratle report were given to the Tow Board. 
D. The Town Board shall review the sketch plan and its related documents. Based thereon, the Town Board shall determine whether or not the pruposal meets the objectives of the PUD section as set forth in Section 59-23 and whether its developnent would be in the public interest. The Tewn. Baard shall within sixty (60) days of receipt: of report of the lianniag Board render a favorable or unfavorible. report and may make such recomendations in connection thercwith as it may deem appropriate. Such determination or recommendations by the Town Board shall be advisory only and shall not constitute approval or disapproval of the plans for the project, nor shall it constitute a commitment or agreement by the Tom Board to tali any further action wether in the nazure of legisliation or otherwise in connection with such proposal.

59-26 Approval of preliminary development plan.

A. If, upon receipt of the determinations and recomendations of the Town Board, the applicant wishes to procecd, he sha11 within six (6) months thereafter submit a preliminary developient plan to the planring Buird. Such development plan shail contain the following infornation propared by a licensed engineer or registered architect:

(1) An area map showing applicant's entire holding, that portion of the applicant's property under consideration, and all properties, subdivisions, streets and casements willin five hundred (500) feet of applicant's property.

(2) If grades exceed three percent (3\%) or portions of the site have soil areas classified by the Soil Conservation Service of the United States Department of Agriculture as having a moderate to high susceptibility to erosion, or a moderate to high susceptibility to flooding and ponding, a topographic map showing contour intervals of not more than five (5) feet of elevation shall be provided.

(3) A preliminary site plan including the following information:

(a) Title of drawing, including name and address of applicant.

(b) North point, scale and date.

(c) Boundaries of the property plotted to scale.

(d) Existing watercourses.

(e) A site plan showing location, proposed use and height of all buildings, location of all parking and truck-loading areas with access drives thereto: location and proposed development of all open spaces including parks, playgrounds and open reservations; location of outdoor storage, if any; location of a 1 l existing or proposed site improvements, including drains, culverts, retaining walls and fences, and any existing trecs over four (4) inches in diameter; description of method of sewage disposal and location of such facilities; location of refuse facilities; location and size of all signs; location and proposed development of buffer areas; location and design of lighting facilities; and the amount of building area proposed for nonresidential uses, if any.

(f) Preliminary plans for handling stormater drainage in accordance with Town of Webster Drainage Control Law. 5

(4) A tracing overlay showing all soil areas and their classifications, and those areas, if any, with moderate to high susceptibility to flooding, and moderate to high susceptibility to erosion. For areas with potential erosion problems, the overlay shall also include an outline and description of existing vegetation. 
(5) Elevations or perspective drawings of proposed structures and improvements iucluding single-family detached residences and their accessory bulldings. The drawings need not be the result of final architectural decisions and need not be in detail.

(6) A development schedule indicating:

(a) The approximate date when construction of the project can be expected to begin.

(b) The stages in which the project will be built and the approximate date when construction of each stage can be expected to begin.

(c) The anticipated rate of development.

(d) The approrimate dates when the development of each of the stages in the development will be completed.

(c) The area and location of common open space that will be provided at each stage.

(7) Agreements, provisions or covenants which govern the use, maincenance and continued protection of the planned development and any of its common open areas.

(8) The following plans and diagrams, insofar as the Planing Board finds that the planned development creates special problems of traffic, parking, landscaping or ccunomic feasibility:

(a) $\Lambda_{u}$ off-street parking and loading plan.

(b) A circulation diagram indicating the proposed movement of vehicles, goods and pedestriaus within the planned development and to and from existing thoroughfares. Any special engineering features and traffic reşulation devices needed to facilitate or insure the safety of this circulation pattern must be shown.

(c) A landscaping and tree planting plan and schedule.

(d) An cconomic feasibility report or tuntket analysis. inary development plan shall inelude, but is not limited to, the following considerations:

(1) Adequacy and arrangement of vehicular traffic access and clrculation, including lntersections, road widths, channelization structures and traffic controls.

(2) Adequacy and arrangement of pedestrian traffic access and circulation including: separation of pedestrian from vehicular traffic, walkway structures, control of intersections with vehicular traffic and pedestrian convenience.

(3) Location, arrangement, appearance and sufficiency of off-strcet parking and loading.

(4) Location, arrangement, size and design of buildings, lighting and signs.

(5) Adequacy, type and arrangement of trecs, shrubs and other landscaping constituting a visual and/or a noise-deterring buffer between adjacent uses and adjoining lands.

(6) In the case of multiple-family dwellings, the adequacy of usable open space for playgrounds and informal recreation.

(7) Adequacy of storm water and sanitary waste disposal facilities.

(8) Adequacy of structures, roadways and landscaping in areas with moderate to high susceptibility to flooding and ponding and/or erosion.

(9) Protection of adjacent properties against noise, glate, unsightliness or other objectionable features.

(10) The relationship of the proposed land uses to adjacent land use and the use of buffer areas and open space to provide a harmonious blending of extsting and proposed uses.

(11) Conformance with other specific recommendations of the Town Board which may have been stated in the Town Board Resolution under Section 59-25D. 
In Its review, the Planning Board may consult with the Town Engineer, architectual or planning consultants, and other town and county officials, as we11 as with represcutatives; of federal and state apencies, including the Soil Conservation Service and the New Yurk State Department of Conserva ion. The planning Board may requile that the design of all structures be made or under the direction of, a registered architect whose seal shall be affixed to the plans. The planning Board may also require such additional provisions and conditions that appear necessary for the public, halth, safety and general welfare.

C. Action on preliminary application. Within sixty (60) days of the receipt of the application for preliminary site plan approval, the Planning Board shall act on it. The Plonning Board's action shall be in the form of a written statement to the applicant and the Town Board stating whethor or not the preliminary site plan is approved.

T. If the Plamning Board approves the preliminary development plan, the Town Bunrl shall hold a public hearing upon a proposition to zone the applicant's lands for the proposed plauned unit development. If after the public hearing the Town Board shall deternine that the proposed development conforms to applicable state, county and town laws, ordinances and regulations, and is in the public interest, it shall adopt a resolution declaring its intention to zone the applicant's property for the proposed planned unit development upon the applicant receiving approval of final plans therefor from the Planning Buard and upon the developer meeting such additional conditions as the Town Board shall deem appopriate in each case and shall set forth in such resolution.

59-27 Approval of final development plan.

A. After receiving notice of zoning intention by the fown Buard, the applicant shall submit a final detailed site plan to the Planning Board which shall substantially conform to the approved preliminary devilopment plan. It shall incorporate any revisions or other features that may have been recommended by the Planning Board and/or Town Buard. The applicant shall also subnit evidence of compliance with all applicable state and county laws and regulations and establish that necessary permits from appropriate govermment: units have been obtained. After the applicant has subitited a final site plan which conforms to the approved prelininary plan revised to comply with Planning and Town Boncl recommeudatinns, and upon complying with such adelitionlal conditinns as may have been set by the Town Buard, the Planning Board shall mark such fiula plans "Approved Final Development Plans," shall. file such plans in the Building Department and notify the Town buard, which shall then enact the legislation to crealte the appropriate planned unit development district. Prior to enacting any legislation, the Town board inay require that a development agreenent be executed and appropriate financial guarantecs be filed to assure compliance with conditions for approval of the development and the minimum requirements of this ordinance. 
B. No building permit shall be issued until the final site development plan has been approved, the zoning change has been enacted by the iown Buard, and, where required by section $280-$ a of the Town Iaw, a plat approved by the Planning; Board in accordance with the provlsions of the fown of liebster Subdivision Regulations 6 has been filed in Monroe County Clerk's office. Such plat shall substantially conform in all respect:s to the approved final site plan and shall be in accordance with the staglng plan submitten to and approved by the Town Board and Planning Board. For a period of two (2) years after adoption of this ordinance, the planning Board shall not approve for filing in the County Clerk's office plats showing more than one hundred fifty (150) multiple-fanily dwelling units in any one (l) planned unit development.

59-28 Development schedule compliance.

A. From time to tine the Elanning Board shall compate the actual development accomplished in the various PuD districts with the approved development schedules. If the owner or owners of property in PUD districts have falled to meet the approved development schedule, the rlanning Board shall so advise the Town Board and shali make such recommendations in connection therewith as they deem appropriate. The Town Board may proceed to rezone the property to the zone classification it held immediately prior to being zoned under this Article. Upon recointendation of the Planning Board and for good cause shown by the property owner, the Town Board may extend the limits of the development schedule.

B. The construction and provision of all of the comnon open spaces and public and recreational facilities which are shown on the final development plan must proceed at the same rate as the construction of dwelline units. At least once every six (6) months following the aboroval of the final development plan, the Building officials shall review all of the building permits issued for the planned development and examine the construction which has taken place on the site. If he shall find that the rate of construction of dwelling units is greater thau the rate at which conmon open spaces and public and recreational facilities have been constructed and provided, he shall forward this information to the Town Board, which may revolke the planned development zone anendment and direct that further building pernits in the development be denied until required recreation or open space is provicled and, if the developer fails or refuses to comply within a reasonable time, may rezone the property to the zone classification it held imadiately prior to being zoned under this Article.

\section{9-29 Changes in final plan after approval.}

In chonges nay be made in the approved final plan during the construction of the planned developinent except upon application to the appropriate agency under the proredurcs proviced below:

A. Minor changes in the location, siting and height, length and width of buildings and structures may be authorized by the planning Board if requixed by engineering or other circumstances not foreseen at the time the final plan was approved. No change authorizcd by this section may increase the cube of any building or structure by more than ten percent, $(10 \%$. 
B. All other changes in use, any rearrangenent of lots, blocks and building tracts, any changes in the provision of common open spaces, and all other changes in the approved final plan, must be approved by the Toun Board, under the proceduices authorized by this ordinance for the amendment of the Zoning Nap. No amendnents ma be ingle in the approved final plan unless they are shomn to be required by changes in conditions that have occurred since the final plan was approved or by changes in the develop- . ment policy of the corriunity.

59-30 Control of planned unit development following completion.

A. Upon completion of the project or any stage thereof for which the developer shall seck i certificate of occupincy or other certificate certifying satisfactory completion of the projurt or portion threxeof, the developer shall submit a certificatce of his; registered architect or licensed cugincer in

form satisfactory to the Planning Board that the completed project, or portion thercof, substantially conforms to the plans therefor aproved by the Planning loard. Upon receipt of such cerlification and baved upon reports of apropriate tow officials, the planing doard shall josue a certificate certifying the conletion of the plamed development, and the clerk of ilice Plaming Board shall nate the isiuance of the certificate on the recorted finsl developinent plan.

B. After the certificate of completion has been issued, the use of land a:d the construction, nodificatian, or alteration of any buildiugs or strastures within the plamed development fill be governad by the approved final developwent plan rather than by auy other provision of this zoning Ordinance.

c. After the certificate of completion has been issued, no changes may be made in the approved final development plan except upon application to the appropriate agency under the proceduras provided below:

(1) hny minor extensions, alterations or modifications of extsting building: or structures may be authorized by the planning Board if they are consistent with the purposes and intent of the final plan. No change authorized by this section may increase the cube of any building or structure by more than ten percent $(10 \%)$.

(2) Any uses not authorized by the approved final plan, but allowable in the planned development as a permitced use under lihe provisions of this Zoniug Ordinamce, may be added to the final developient plan upon receipt of approval of the plannitig lioard.

(3) $\Lambda$ building o: structure that is cotally or suhtatanially destroyed thay be reconstructed only in compliance with tise final development plan unless an ariendment to the final development plan is approved as provided herein.

(4). Changes in the use of common open space nay be nuthorizud by an amendment to the final developterist plan undier subsection ( 5 ) below.

(5) Al1 other changes in the final. developaent plan nust be approved by the Tom Bond, under the procedures authorized by Lhis ordinance for the acendent of the roning Nap. Ho changes rialy be made in the fiul developirat plan unass they are reyuired for the continued successful functioning of the planned developnent, or undess they are required by chauges in couditions that have occurred since the final plan was approved or by changes in the development policy of the community. 
D. Ho changes in the final development plan wich are approved under this Section are to be considered as a waver of the covenants limiting the use of land, buildings, structures and improvenents vithin the area of the planned development, and all rights to enforce these covenants against any changes permited by tinis section are expressly reserved.

59-31 Legislative intent.

1. It is the intention of the Twon Board in orler to encourage the blending and mixture of various types of housing to create, upon proper application, planned multiple-family residential districts to be located within zoning districts only as such are desicrnated on the official \%oning Map. Such planaed mutiple-fanily residential dictricts shall be approved by the Town hoard based upon compliakes with this ordinance, the avidability and alcequicy of sowerage facilitics, public ticansurtation, drainage, together with conslderation of topograpical and land characteristics and the suitability of development as all of the above affects the health, welfare: and safety of the residents of Hebster.

B. In order to pronote the orderly development of the tom, provide adequate fire and folice protection, sanitary and stormater drainase facilities, and to promote the feneral health, safety and welfare of the town, it is the determination of the Town Board based upon the compathensive plen and the character of the contunity that mulpiple-dedelings shall at no

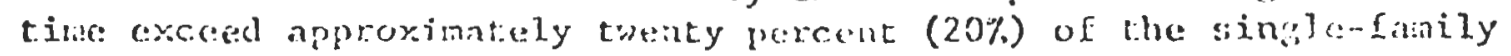
detached dmellings in the forn of Webster, excluding the Villege of Webser.

C. The purposes of standards hereinater sct forth are to insure compatability anong all the land tises, foster iunovation in site plannin:s and revelopnent,

and eucourage sound developalent in tib julerest of safecy and ganeral welfare of thie puisic. The standards for plarmed unit distriets ate to

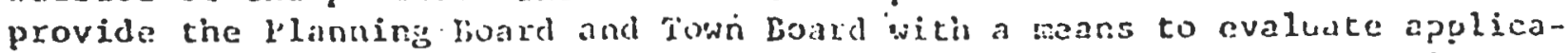
tions for these districts consistent with the provisions and genersi illtent of the Zoning Ordinance. Such standards are incended to strengthen public control over development, while providing the neccssary latilule for the developer to make creative and efricient use of property. 


\section{PERMITS/REVIEWS REQUIRED}

\section{Lócal Permits/Reviews:}

1. Rezoning/site plan approval by Planning Board and Town Board

2. Sewer Line extension/connection approval by Webster Sewer System.

3. Water line extension/connection approval by hebster Water System.

\section{County Permits/Reviews:}

1. 239 m Review by County Planning Department on rezoning and/or site plan approval by tom. 30 day review porici.

2. County Department of Public lierks:

239-k review of proposed access to site; 10 day ruview period

136 review of work within courty right-of-way for driveways, utilities, drainage, elc. 10-20 day review period.

3. County Health Department:

Artjcle 17 review of proposed sewer extensjon/cunnectionsi.

Article 225 review of proposed water main extensions or connections. Ahove permils may be combined in 30 day review period.

4. Real Property Tax Service Agency - Must review final plans prior to filing with County Clerk if subdivision is involved.

10 day review period.

\section{State Permits/Reviews:}

1. New York State Department of Transportation:

Section 52 permit for work within State Highway Right-of-way; review of proposed access design and construction, drainage, and utilitics affecting a state highway right-of-way. 10 day review period.

2. Article 8 Part 617 State Environmental Quality keview Act (SEO!R):

a. Environmental Assessment Form must be prepared if project is a type I action: Conmercial zoning change affecting 10 or more acres; commercial project involving physical alteration of 10 acres; parking for 1000 or more vehicles; substantially contiguous to publicly owned and operated park land.

b. EAF must be matled to all permit granting agencies for review (30 day review period).

c. After review of EAF, lead agency must be assigned from permit granting agencies.

d. Within 15 days of step c. a determination of significance sha]l be made (positive or negative declaration) and shall be mailed to all involved agencies. 
e. Upon a positive declaration, lead agency shall cause a draft Environmental Impact Statement (DLIS) to be prepared. Upon completion of the DEIS, 30 day review period and optional public hearing commence.

f. A final EIS shall be prepared within 45 days of hearing or 60 days from preparation of DEIS, whichever is latest.

g. If a determination is made from DEIS that there will be no significant effect on environment, a final EIS is not required.

h. If a final EIS is prepared, a 10-30 day review period is required and the final EIS must be considered and recognized in the final decision on permit granting.

POSSIBLE PERMIT/REVIEW PROCESS:

1. Applicant submits sketch plan to planning Board for review including EAF.

2. EAF distributed to permit-granting agencjes and lead agency determined.

3. Lead agency determines significance of possible impacts and makes positive or negative declaration.

4. If negative declaration, applicant submits preliminary plans (step 6). If positive declaration, lead agency asks applicant to prepare DFIS.

5. DEIS prepared submitted to permit agencies for 30 day review.

6. Applicant prepares prelininary plans and submits to Lown, County planning Health and DPW and NYSDOT for permit granting revicw.

7. Permit agencies comment on preliminary aplication and JEIS.

8. Lead agency determines if Final EIS is required, holds public hearing.

9. Lead Agency determines final environmental impact; tom grants pormits for project. 